Int. J. Plant Sci. 178(8):650-672. 2017 (C) 2017 by The University of Chicago. All rights reserved.

This work is licensed under a Creative Commons Attribution-NonCommercial 4.0 International License (CC BY-NC 4.0), which permits non-commercial reuse of the work with attribution. For commercial use, contact journalpermissions@press.uchicago.edu. 1058-5893/2017/17808-0007\$15.00 DOI: 10.1086/693108

\title{
SAPORTANTHUS, AN EXTINCT GENUS OF LAURALES FROM THE EARLY CRETACEOUS OF PORTUGAL
}

\author{
Else Marie Friis, ${ }^{1, *}$ Peter R. Crane, + and Kaj Raunsgaard Pedersen‡ \\ *Department of Paleobiology, Swedish Museum of Natural History, Stockholm, Sweden; +Oak Spring Garden Foundation, \\ Upperville, Virginia 20184, USA; and Yale School of Forestry and Environmental Studies, New Haven, \\ Connecticut 06511, USA; and ¥Department of Geoscience, University of Aarhus, Aarhus, Denmark
}

Editor: Michael T. Dunn

\begin{abstract}
Premise of research. Numerous exquisitely preserved fossil floral structures recovered from Lower Cretaceous sediments in Portugal are invaluable for understanding the organization and structure of flowers at an early stage in angiosperm evolution. This study analyses three such flowers that add significantly to current knowledge of structural and systematic diversity among very early eumagnoliid angiosperms.
\end{abstract}

Methodology. Fossil flowers were extracted from unconsolidated sedimentary rocks by sieving in water. Morphological and anatomical details were studied using scanning electron microscopy and synchrotron radiation X-ray tomographic microscopy. The phylogenetic position of the fossils was assessed using the available morphological data sets for extant taxa.

Pivotal results. A new genus, Saportanthus, with three new species, S. brachystemon, S. dolichostemon, and S. parvus, is described from the Early Cretaceous of the Lusitanian Basin, western Portugal, based on coalified flowers. The flowers are small, actinomorphic, and structurally bisexual with semi-inferior ovary. Floral organs are apparently spirally arranged and variable in number. The perianth consists of six to eight tepals, and the androecium consists of five to 15 stamens. The stamens are almost sessile with basifixed, dithecate, and tetrasporangiate anthers. The thecae are separated by a massive connective. The four laterally placed pollen sacs protrude and dehisce by four laterally hinged valves that extend for the full length of the anther. Pollen grains are circular in polar view, trichotomocolpate or dicolpate, with a thin continuous tectum and granular infratectal layer. On the distal surface the tectum is psilate-punctate around the aperture but finely striate proximally with delicate ridges that form a distinctive fingerprint-like pattern. The gynoecium is semi-inferior and syncarpous with one to three locules and a single, apical, pendulous ovule in each locule. The stylar area is conical with one, two, or three short styles. The fruit is indehiscent and probably drupaceous, sometimes with only a single seed. Phylogenetic analyses based on the features of the fossil flowers place Saportanthus in Laurales, either as sister to core Laurales or as close to the clade comprising Lauraceae and Hernandiaceae.

Conclusion. Flowers of Saportanthus possess a combination of characters that indicate a relationship to extant Laurales but that is unknown among extant or fossil members of the group. Saportanthus provides further evidence of extensive extinction in the early diversification of angiosperms, including in the early phases of evolution that ultimately gave rise to living groups.

Keywords: dicolpate, early angiosperms, fossil flowers, Laurales, Saportanthus, trichotomocolpate.

\section{Introduction}

Modern phylogenetic analyses based on molecular data resolve extant Amborellales, Nymphaeales, and Austrobaileyales as successive sister groups to all other angiosperms, which in turn comprise five clades: Ceratophyllaceae, Chloranthaceae, eumagnoliids, monocots, and eudicots. Together these five groups include more than $99 \%$ of all angiosperm species. Consistent

1 Author for correspondence; e-mail: else.marie.friis@nrm.se.

Manuscript received March 2017; revised manuscript received May 2017; electronically published August 18, 2017. with their predicted early divergence, four of these groups (Chloranthaceae, eumagnoliids, monocots, and eudicots) have a fossil history extending back into the Early Cretaceous (Friis et al. 2011). Prominent among the early fossil record of angiosperm flowers are fossils of Laurales, one of the four orders (with Canellales, Magnoliales, and Piperales) that comprise extant eumagnoliids (APG 2016).

Current concepts of Laurales recognize Calycanthaceae as the sister group to six other families (core Laurales) forming two clades: Siparunaceae (Gomortegaceae-Atherospermataceae) and Hernandiaceae (Monimiaceae-Lauraceae; Renner 1999; see also Renner and Chanderbali 2000). Early Cretaceous fossil flowers that can be reliably assigned to Laurales include several 
undoubted core Laurales (Potomacanthus lobatus, Cohongarootonia hispida, and Powhatania connata; von Balthazar et al. 2007) as well as one (Virginianthus calycanthoides) that is closely similar to flowers of Calycanthaceae (Friis et al. 1994a). In this article we add to the Early Cretaceous record of Laurales through the description of a new genus with three species based on exceptionally well-preserved fossil flowers from the Early Cretaceous of Portugal. All three species have a suite of distinctive features that is unknown among extant Laurales. Together they underline the importance of extinction in the early evolutionary history of an extant group that is important today but that also has a fossil history extending back more than $100 \mathrm{Myr}$.

\section{Material and Methods}

The Early Cretaceous flowers described here include more than 200 specimens isolated from rich mesofossil floras collected at six different localities in the Lusitanian Basin of western Portugal: Arazede, Buarcos, Catefica, Famalicão, Vale de Água, and Vila Verde 2 (for maps and further information on Early Cretaceous mesofossil occurrences in Portugal, see Friis et al. 2010, 2011). The Catefica locality is the most southerly in the Lusitanian Basin and is probably the oldest of the six localities.

The sediments at the Catefica locality belong to the Almargem Formation (late Barremian-Albian; Rey 1993), which is exposed in a roadcut near the village of Catefica close to Torres Vedras on the western margin of the Runa subbasin. The exact stratigraphic position of the sediments exposed at the Catefica locality is uncertain. They may be equivalent to the basal part of the Figueira da Foz Formation (late Aptian-early Albian), but comparison with other mesofossil assemblages in the Torres Vedras-Runa area indicates that the Catefica mesofossil assemblages could be older within the Aptian (see discussion in Friis et al. 2015, 2017).

The Vale de Água mesofossil flora is from a complex of large clay pits in sediments previously assigned to the Complexos gresosos de Nazaré e de Cós-Juncal, which are stratigraphically near the base of the Figueira da Foz Formation (Famalicão Member; Dinis 2001; Dinis et al. 2002, 2008; Rey et al. 2006). A position in the basal part of the Figueira Formation (Calvaria Member) is also inferred for the mesofossil floras from Buarcos, Vila Verde 2, and Arazede. The Buarcos locality was an exposure along the old road between Buarcos and Tavarede that has now been destroyed by city development (Friis et al. 2011). The Vila Verde 2 locality is a clay pit northeast of Figueira da Foz. The Arazede locality is a road exposure near the village of Arazede north of Montemor-o-Vehlo. The Famalicão mesofossil flora was collected from a large, deep clay pit close to the village of Famalicão that is now abandoned and infilled. However, in the late 1980s the pit exposed sediments of the Figueira da Foz Formation. The mesofossils were collected in the deepest part of the clay pit in sediments, below the basal conglomerates of the Figueira da Foz Formation, indicating a late Aptian (or older) age.

Fossil flowers were extracted from the sediments and prepared for analysis using standard techniques (Friis et al. 2011). The fossils are coalified; most are lignitized, and only a few specimens are charcoalified. Two specimens (S107752, S107775) were embedded in 2-hydroxyethyl methacrylate and sectioned using a rotary microtome. For SEM, fossils were mounted on stubs with nail polish, sputter coated with gold, and examined using a Hitachi Field S-4300 FE-SEM at 2kV (a Philips SEM 515 in the case of older images). Internal features were analyzed for 17 specimens (S100757, S101304, S135458, S135459, S174163, S174164, S174165, S174172, S174173, S174301, S174357, S174436, S174493, S174786, S174787, S174788, S174789) using synchrotron radiation X-ray tomographic microscopy (SRXTM) at TOMCAT Beamline, Swiss Light Source, Paul Scherrer Institute, Villigen, Switzerland (Stampanoni et al. 2006). For SRXTM, the fossils were attached to the brass stubs with nail polish. Measurements were performed at $10 \mathrm{keV}$ using a $10 \times$ objective (isotropic pixel size of $0.65 \mu \mathrm{m}$ ) and a $20 \times$ objective (isotropic pixel size of $0.325 \mu \mathrm{m}$ ) using a sCMOS detector and a 20- $\mu$ m-thick LAG: Ce scintillator screen (for further details on SRXTM for fossil plants, see Friis et al. 2014). Virtual slices and reconstructions based on the SRXTM data were made using Avizo software (ver. 5-9.1.1). Adobe Photoshop CS5 was used to label orthoslices and give an even black background to the SEM images.

All specimens and raw data from the SRXTM study are stored at the Swedish Museum of Natural History, Stockholm, Sweden (S).

\section{Results}

Description of the Fossils and Taxonomic Treatment

$$
\begin{aligned}
& \text { Angiospermae } \\
& \text { Order_Laurales }
\end{aligned}
$$

Saportanthus gen. nov.

Derivation of generic name. In honor of the French paleobotanist Gaston de Saporta (1823-1895), in recognition of his pioneering studies of the Mesozoic floras of Portugal.

Generic diagnosis. Flower small, actinomorphic, structurally bisexual with a semi-inferior ovary. Phyllotaxis of tepals and stamens apparently spiral. Perianth with six to eight tepals, tepal bases broad. Androecium of five to 15 stamens with almost sessile, basifixed anthers. Anthers dithecate and tetrasporangiate; thecae separated by a broad connective; dehiscence latrorse to extrorse by four laterally hinged valves that extend for the full length of the anther. Pollen circular in polar view; trichotomocolpate or dicolpate; pollen wall thin, tectate with thin granular infratectal layer. Tectum ornamentation finely striate proximally with delicate ridges forming a fingerprint-like pattern; psilate-punctate distally around the aperture(s). Gynoecium syncarpous, of one to three carpels; ovary with one to three locules. One ovule per carpel, apical and pendulous; ovules anatropous, small, not filling the ovary cavity. Inner lining of ovary wall (endocarp) with several layers of narrow, longitudinally aligned sclerenchyma cells. Stylar area conical with two or three short styles. Fruit indehiscent, drupaceous; seeds one to three; seed coat thin with a finely reticulate surface.

Type species designated here. Saportanthus dolichostemon sp. nov.

Saportanthus dolichostemon sp. nov. (Figs. 1-5)

Derivation of specific name. From the long stamens (Greek dolichos [long] and stemon [stamen]). 

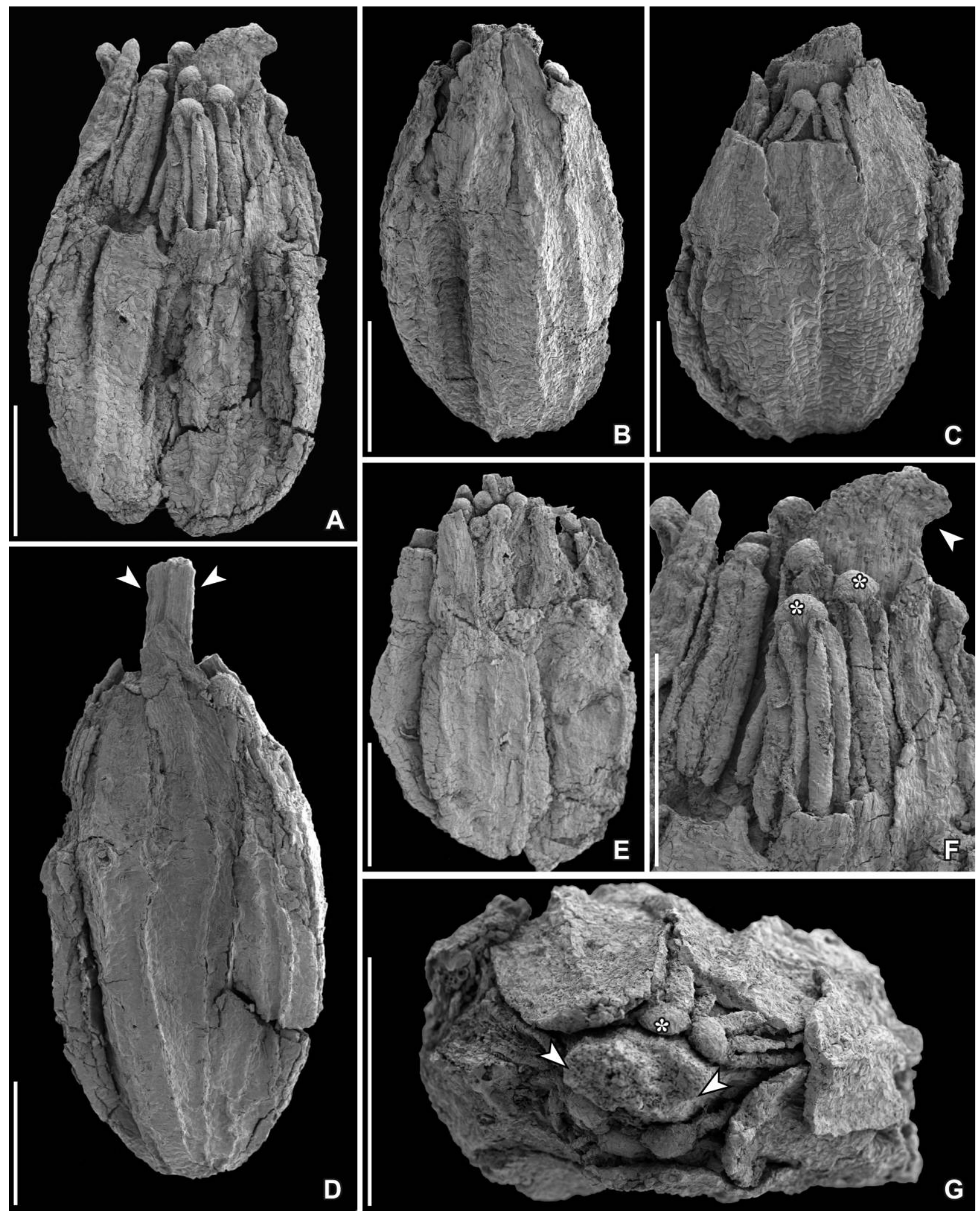

Fig. 1 SEM images of flowers of Saportanthus dolichostemon gen. et sp. nov. from the Early Cretaceous Vale de Água locality, Portugal, showing flowers with narrow triangular tepals and elongated stamens that are inserted about two-thirds of the way up the semi-inferior ovary. $A$, Holotype; flower in lateral view showing two tepals broken near their base exposing the almost sessile, elongated, dehisced anthers, each with laterally hinged valves and an apical dome-shaped extension of the connective (S174166, sample Vale de Água 408). B, Flower in lateral view with well-preserved tepals (six visible on rotating the specimen; S135458, sample Vale de Água 383). C, Flower in lateral view showing tepals 
Specific diagnosis. As for the genus with the following additions. Tepals six to eight, narrow triangular. Stamens 10 15 , mostly 10 , up to $0.7 \mathrm{~mm}$ long, about three times longer than wide. Pollen trichotomocolpate. Carpels two; ovary wall thin. Ventral-lateral bundles thin and separate near the top of ovary, united further down. Ovary wall glabrous. Fruit with one or two seeds.

Distinguishing features for Saportanthus dolichostemon. See "Discussion."

Holotype. S174166 (sample Vale de Água 408) designated here (fig. $1 A, 1 F$ ).

Paratypes. S105030, S105912, S105913 (sample Vale de Água 19), S101304, S101332, S101333, S101335, S122010, S122011 (sample Vale de Água 141), S174323 (sample Vale de Água 215), S174848 (sample Vale de Água 265), S174180 (sample Vale de Água 328), S174774 (sample Vale de Água 329), S174776 (sample Vale de Água 330), S174172 (sample Vale de Água 363), S125004, S125005, S125006, S174849 (sample Vale de Água 364), S135458, S135459 (sample Vale de Água 383), S174850 (sample vale de Água 384), S174164, S174165, S174851 (sample Vale de Água 408).

Other material. S174328-S174330, S174836 (sample Arazede 372), S174357, S174839 (sample Arazede 374), S101223S101227, S101356, S105905-S105911，S174781-S174784, S174964-S174966 (sample Famalicão 25), S174789 (sample Vila Verde 2 438), 174331-S174333 (sample Vila Verde 2439 ).

Type locality. Vale de Água, Portugal $\left(39^{\circ} 37^{\prime} 15^{\prime \prime} \mathrm{N}, 08^{\circ} 51^{\prime}\right.$ $\left.30^{\prime \prime} \mathrm{W}\right)$.

Type horizon and age. Early Cretaceous (late Aptian-early Albian; basal part of the Figueira da Foz Formation).

Description of Saportanthus dolichostemon. The new species is based on about 25 flowers from the Vale de Água locality (type locality), about 10 flowers from the Arazede locality, 70 specimens from the Famalicão locality, and three specimens from the Vila Verde 2 locality. One poorly preserved flower is also reported from the Chicalhão site near Juncal, Portugal, as flower 3 (Mendes et al. 2014). Eight flowers were analyzed using SRXTM. The best preserved specimens are from the Vale de Água locality. These flowers often have perianth and androecium intact, have pollen in situ in the stamens, and also have informative internal features, such as ovules and placentation, preserved (figs. 1-5). However, fossil flowers with the characteristic features of $S$. dolichostemon, including pollen in situ, are also known from the four other localities. In all cases flowers are isolated, and there is no information how they were borne on the plant.

Flowers and fruits are elliptical to ovate in lateral view, small, about $1.5-2.1 \mathrm{~mm}$ long and $1-1.2 \mathrm{~mm}$ in diameter, and structurally bisexual (figs. 1-4). The ovary is semi-inferior, with the tepals and stamens inserted about two-thirds of the way up the ovary. The perianth consists of six to eight undifferentiated te- pals, apparently in a spiral arrangement (figs. $1 B-1 D, 1 G, 2 A-$ $2 I$ ). Tepals are narrowly triangular with a pointed tip and broad attachment (figs. $1 B, 1 D, 1 E, 2 A-2 C$ ). In well-preserved specimens, the tips of the tepals appear slightly modified (fig. $2 A-$ $2 C$ ). Each tepal has a single median bundle (fig. $2 D-2 H$ ). Tepals are slightly longer than stamens and closely appressed to them (figs. $1 A-1 G, 2 A-2 C$ ).

The androecium consists of 10 to 15 stamens, apparently also in a spiral arrangement (fig. 2D-2I). Stamens are elongate, about $0.7 \mathrm{~mm}$ long, about three times longer than wide with almost sessile and basifixed anthers. Stamen bases are about $0.05 \mathrm{~mm}$ long and broad. The anthers are dithecate and tetrasporangiate (fig. $1 \mathrm{~A}, 1 \mathrm{~F}$ ). The connective between the thecae is broad, with a single vascular bundle (fig. $2 D-2 H$ ) and a prominent dome-shaped apical expansion (figs. $1 A, 1 C, 1 E-1 G, 2 A-$ $2 C, 4 A$ ). Dehiscence is latrorse to extrorse by longitudinal slits that bifurcate beneath the dome-shaped extension of the connective, resulting in four laterally hinged valves (fig. $1 \mathrm{~A}$ ).

Pollen grains have been observed in situ in many flowers. They are mostly preserved with the aperture facing toward the center, but many grains have the distal (apertural) surface exposed and show the aperture well. Pollen grains are more or less circular in polar view, about $13-15 \mu \mathrm{m}$ in diameter, and typically strongly flattened. In all specimens the aperture is trichotomocolpate (fig. 5C, 5E, 5F). The pollen wall is very thin and composed of a thin tectum and a thin granular infratectal layer that is sometimes exposed in abraded grains. The tectum is finely striate on the proximal (nonapertural) face with thin ridges that form a fine fingerprint-like pattern. Sometimes there are minute pores between the ridges (fig. $5 A, 5 B, 5 D$ ). On the distal face the aperture has three radiating arms (fig. $5 C, 5 D$ ). The aperture membrane is granular (fig. $5 F$ ) with a broad zone of psilatepunctate tectum bordering the aperture.

All specimens of $S$. dolichostemon investigated using SRXTM have a gynoecium of two carpels. The gynoecium is syncarpous and bilocular. Above the insertion of tepals and stamens, the gynoecium is slender and conical; below it is elongated and rounded. The ovary has two short styles at the apex (figs. $1 D, 1 F, 2 A-2 C$, $4 A, 4 C)$, but in all cases the styles are broken and there is no information about the stigma.

There is a single ovule in each locule (figs. $2 D-2 I, 3 A-3 D$, $4 D)$. Each ovule is small, anatropous, apical, and pendulous and does not fill out the ovary cavity (figs. 3D, $4 E, 4 F$ ). Ovules are apparently bitegmic. The carpel wall is thick with an inner lining of narrow, longitudinally arranged sclerenchyma cells, up to about five cells deep (figs. $2 G, 2 I, 3 A, 3 C, 4 E, 4 F$ ). To the outside of the sclerenchyma layer is a layer of tiny square cells that resemble crystal cells, which is followed by an outer zone of thin-walled cells that are filled with amorphous material. Each carpel has a dorsal and two ventral-lateral vascular bundles. The dorsal bundle remains the same size and orientation for

(seven visible on rotating the specimen). Note some broken tepals near the apex, exposing the tips of stamens and styles (S174172, sample Vale de Água 363). D, Flower in lateral view showing four tepals (six visible on rotating the specimen), stamens (mainly obscured), and two slender styles (arrowheads) that extend beyond the perianth and androecium (see also virtual sections in fig. 2F, 2G; S135459, sample Vale de Água 383). E, Flower in lateral view showing partly exposed stamens (S174180, sample Vale de Água 328). F, Detail of the flower in $A$ showing stamens, almost sessile anthers, dome-shaped apical extensions of each anther connective (two with asterisks), and one stylar branch (arrowhead). Note that anthers dehisce by four laterally hinged valves (S174166, sample Vale de Água 408). G, Apical view of the flower in $C$ showing seven tepals; eight stamens, each with a distinct apical extension of connective (one with asterisk); and two styles (arrowheads; S174172, sample Vale de Água 363). Scale bars $=500 \mu \mathrm{m}$. 

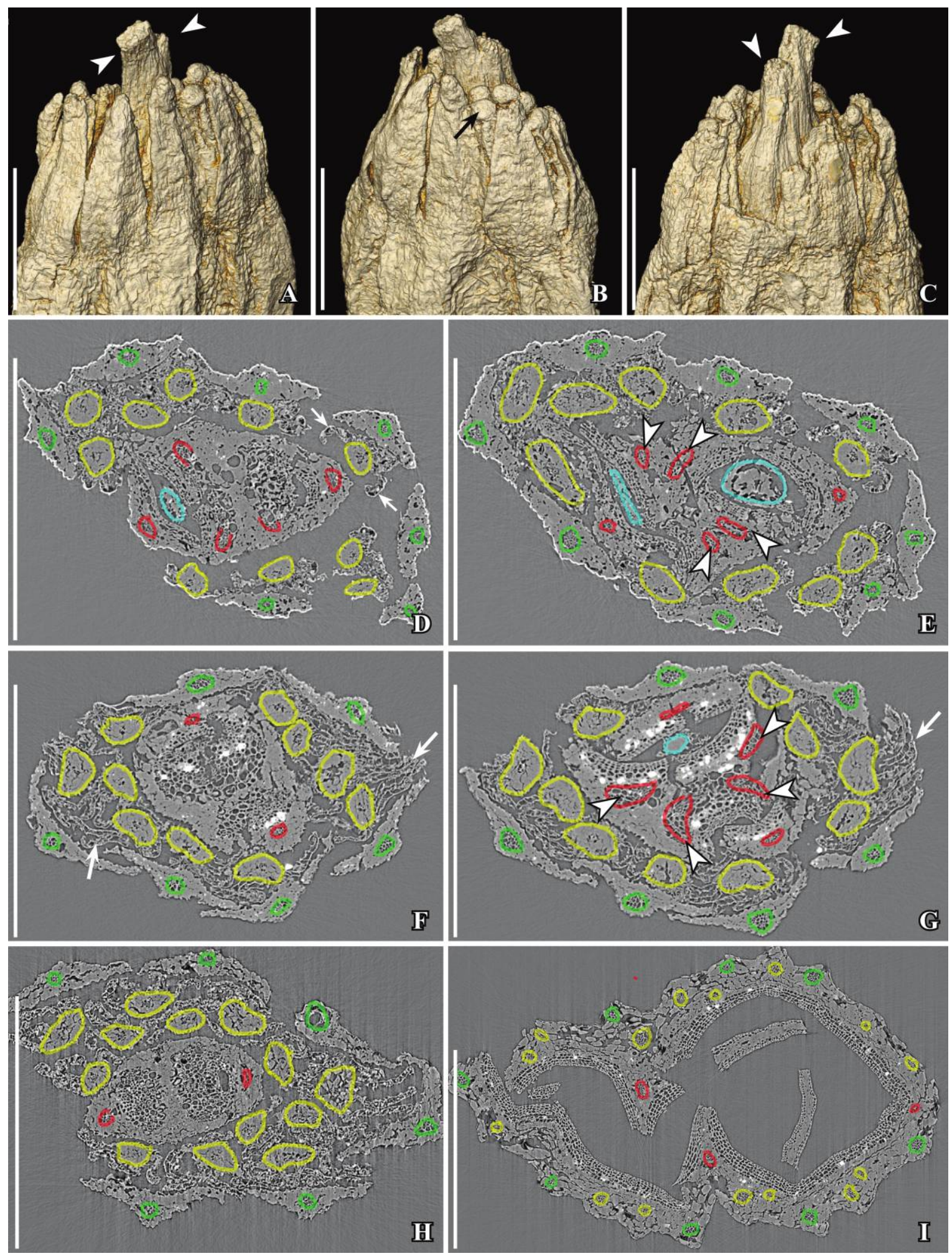

Fig. 2 Synchrotron radiation X-ray tomographic microscopy images of a flower of Saportanthus dolichostemon gen. et sp. nov. from the Early Cretaceous Vale de Água locality, Portugal (volume renderings, $A-C$; transverse orthoslices, $D-I$ ). Note the median tepal bundles (green), stamen connectives (yellow), laterally hinged anther valves (arrows), carpel bundles (red), and ovules (blue); also note the two ventral bundles per carpel (arrowheads in $E, G)$. A-C, Apical part of a flower in three lateral views showing tepal shape, apical dome-shaped extensions of connectives (black arrow in B), and two styles (arrowheads in A, C; S101304, sample Vale de Água 141). D, E, Transverse orthoslices of the flower in $A-C$ at two different levels $(D$, orthoslice xy0760; $E$, orthoslice xy0990) showing eight tepals (seven in $D)$, 10 stamens, the bicarpellate ovary in which each carpel has a dorsal bundle, two ventral bundles (arrowheads in E), and one ovule (blue) in a single 

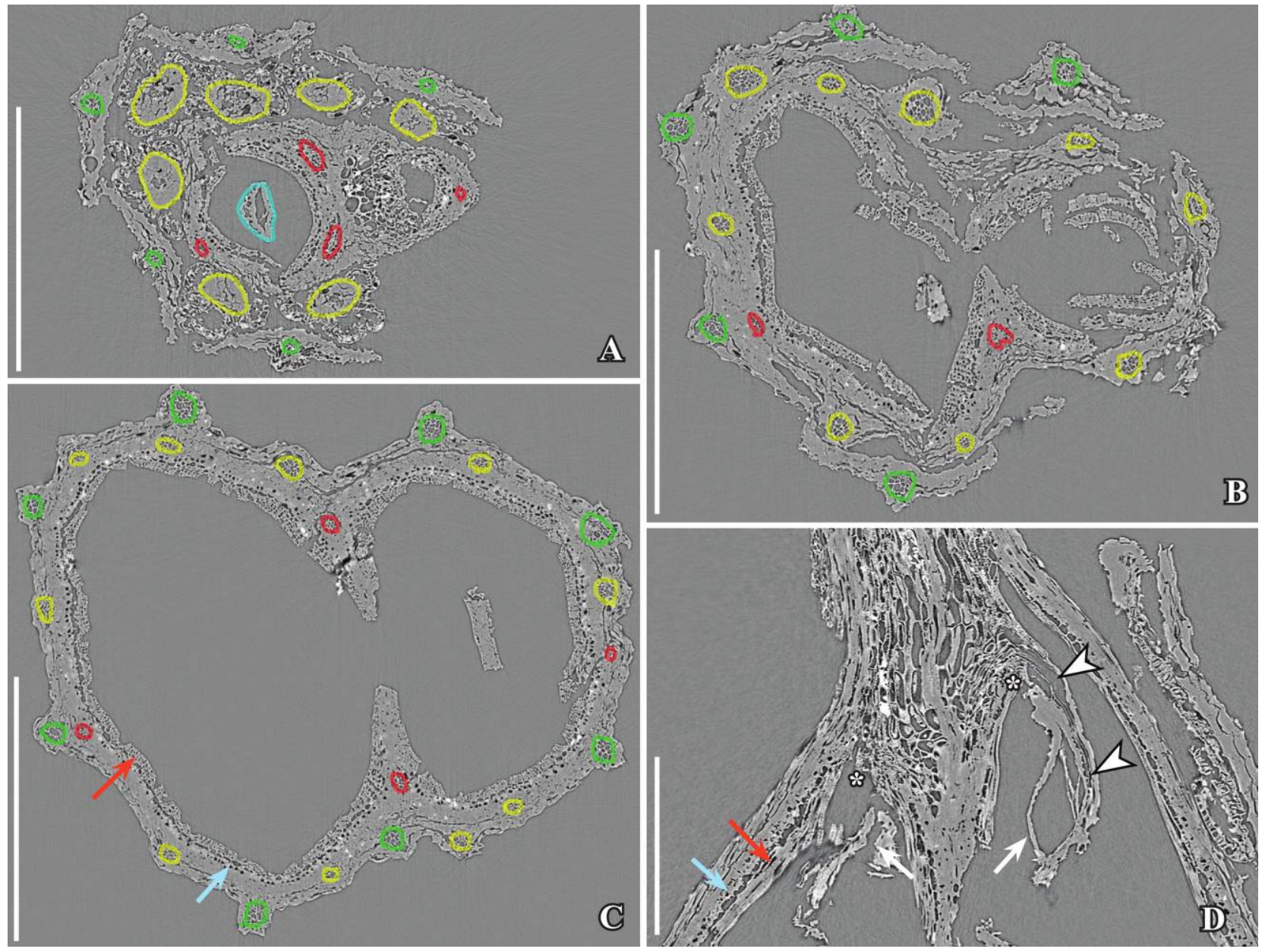

Fig. 3 Synchrotron radiation X-ray tomographic microscopy images of a flower of Saportanthus dolichostemon gen. et sp. nov. from the Early Cretaceous Vale de Água locality, Portugal (same flower as in fig. 4; S174164, Vale de Água 408). A-C, Transverse orthoslices through the flower near the apex of the ovary $(A$, orthoslice xy1120), close to $(B$, orthoslice xy1580) and below (C, orthoslice xy1940) the level of insertion of tepals and stamens. Note the eight tepals (five in $A, C$; median bundle in green), 10 stamens or stamen bundles (seven in $A$, nine in $B$; in yellow), two carpels (carpel bundles in red), and one of the two ovules ( $A$, in blue); also note that the ovary cavity is lined with a layer of narrow sclerenchyma cells about five cells deep (red arrow) with a layer, one cell deep, of tiny square cells (blue arrow) externally. $D$, Longitudinal orthoslice (yz0810) through the central part of the flower showing one pendulous anatropous ovule in each locule (arrow; asterisks indicate points of ovule attachment); the ovule to the right shows a well-preserved raphe (arrowheads). Note the tiny square cells (blue arrow) and inner layer of sclerenchyma cells (red arrow) in the ovary wall. Scale bars $=500 \mu \mathrm{m}(A-C), 250 \mu \mathrm{m}(D)$.

the full length of the carpel. The two ventral-lateral bundles from each of the two carpels are separate in the apical part of the ovary but are united further down (figs. $2 D-2 I, 3 A-3 C$ ). The outer wall of the hypanthium is composed of thin-walled cells similar to the cells of the outer carpel wall. In both cases, the resulting structures are interpreted to have been fleshy.

One compressed and slightly abraded fruit (S101332) has a single seed and apparently only a single locule. This specimen was too compressed for SRXTM analysis. In this specimen, the seed fills the whole space inside the fruit wall and has a thin, finely reticulate seed coat.

\section{Saportanthus brachystemon gen. et sp. nov. (Figs. 6-10)}

Derivation of specific name. From the short stamens (Greek brachys [short] and stemon [stamen]).

Specific diagnosis. As for the genus with the following additions. Tepals six to eight, broadly triangular. Stamens six to 10 , up to $0.55 \mathrm{~mm}$ long, up to two times longer than wide. Pollen dicolpate and trichotomocolpate. Carpels two to three. Ovary wall thick. Ventral-lateral bundles broadly horseshoe shaped near top of ovary, thinner further down. Ovary wall glabrous. Fruit with one to three seeds.

locule. $F, G$, Transverse orthoslices of the flower in $D$ at two different levels ( $F$, orthoslice xy1075; $G$, orthoslice xy1250) showing six tepals, 10 stamens, and two carpels, of which one has a single ovule (marked in blue) in the locule (S135459, sample Vale de Água 383). H, I, Transverse orthoslices of the flower near the top of the ovary $(H$, orthoslice xy0865) and through the ovary below the insertion of perianth and androecium (I, orthoslice xy1965) showing eight tepals (six in $H$ ) and at least 15 stamens. Note the connectives of 13 stamens in $H$ and 15 stamen bundles in $I$ (S174165, sample Vale de Água 408). Scale bars $=500 \mu \mathrm{m}$. 

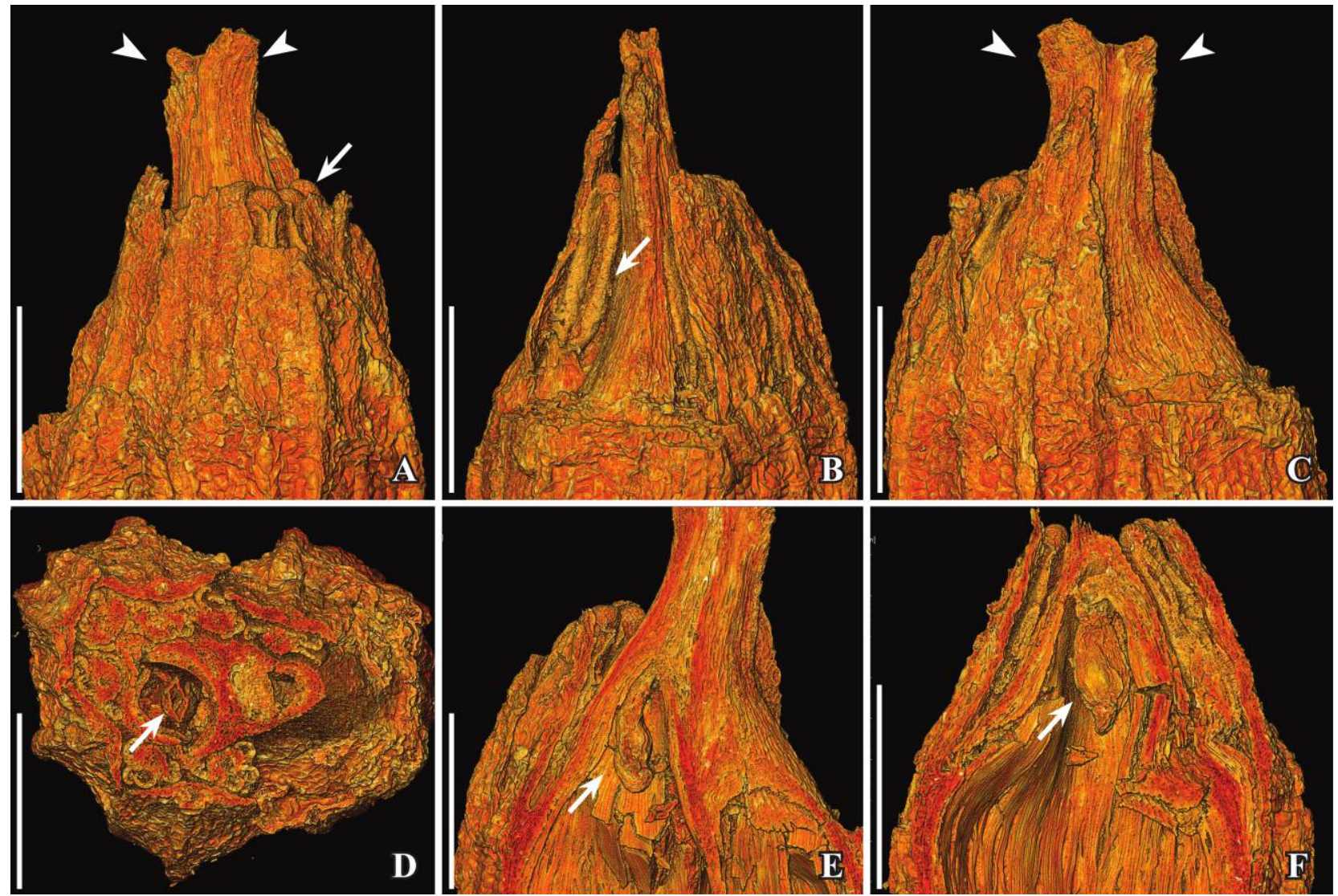

Fig. 4 Synchrotron radiation X-ray tomographic microscopy images (volume renderings) of a flower of Saportanthus dolichostemon gen. et sp. nov. from the Early Cretaceous Vale de Água locality, Portugal (same flower as in fig. 3; S174164, Vale de Água 408). A-C, Apical part of the flower in three lateral views showing narrowly triangular tepals; elongated stamens, each with a dome-shaped apical extension of connective (arrow for one stamen in $A$ ); dehisced anther (arrow in $B$ ); and two stylar branches (arrowheads in $A$ and $C$ ). $D$, Transverse-cut volume rendering (cut at orthoslice xy1000) through the apical part of gynoecium showing a single ovule in one of the two locules (arrow). $E, F$, Longitudinal-cut volume renderings ( $E$ cut at yz0733; $F$ cut at xz0822) showing an apical pendulous ovule (arrows) and the narrow elongate sclerenchyma cells that line each locule. Scale bars $=500 \mu \mathrm{m}$

Distinguishing features for Saportanthus brachystemon. See "Discussion."

Holotype. S174324 (sample Vale de Água 215), designated here (figs. 6A, 9B, 9I).

Paratypes. S101336, S101338-S101347, S105915, S174852 (sample Vale de Água 19), S101286-S101288, S101295, S101296, S101324，S101326-S101331，S101334，S174327，S174787 (sample Vale de Água 141), S174323 (sample Vale de Água 215), S174493, S174842, (sample Vale de Água 300), S174436, S174843 (sample Vale de Água 328), S174775, S174844 (sample Vale de Água 329), S174173 (sample Vale de Água 363), S125007, S125008, S153501, S174334, S174335, S174845 (sample Vale de Água 364), S135456, S175457 (sample Vale de Água 383), S174788 (sample Vale de Água 384), S174163, S174786, S174846, S174847 (sample Vale de Água 408).

Other material. S174837 (sample Arazede 373), S174838 (sample Arazede 374), S174840, S174841 (sample Buarcos 243).

Type locality. Vale de Água, Portugal $\left(39^{\circ} 37^{\prime} 15^{\prime \prime} \mathrm{N}, 08^{\circ} 51^{\prime}\right.$ $\left.30^{\prime \prime} \mathrm{W}\right)$.

Type horizon and age. Early Cretaceous (late Aptian-early Albian; basal part of the Figueira da Foz Formation).
Description of Saportanthus brachystemon. About 54 flowers were recovered from the Vale de Água locality (type locality), and a few specimens have also been recovered from the Arazede and Buarcos localities. Seven flowers were analyzed using SRXTM (figs. 7, 8). The material consists of flowers and fruits in which remains of tepals and stamens are generally present but typically not well preserved. However, information on organs that are missing can be retrieved from the SRXTM reconstructions because these often show the vascular bundles from tepals and stamens as well as other internal features. Pollen grains are found in situ in many of the flowers. All flowers and fruits are isolated, and there is no information how the flowers were borne on the plant.

Flowers and fruits are ovate to broadly ovate in lateral view, about $1.4-2 \mathrm{~mm}$ long and $0.8-1.6 \mathrm{~mm}$ in diameter, structurally bisexual (figs. $6 A-6 I, 7 B, 8 B$ ). The ovary is semi-inferior with tepals and stamens inserted about halfway up the ovary. The perianth consists of six undifferentiated tepals (apparently five in specimen S101295). Tepals are broadly triangular with a pointed tip and broad attachment (fig. $6 C, 6 D, 6 F$ ). Each tepal has a large median bundle and several smaller, lateral bundles 

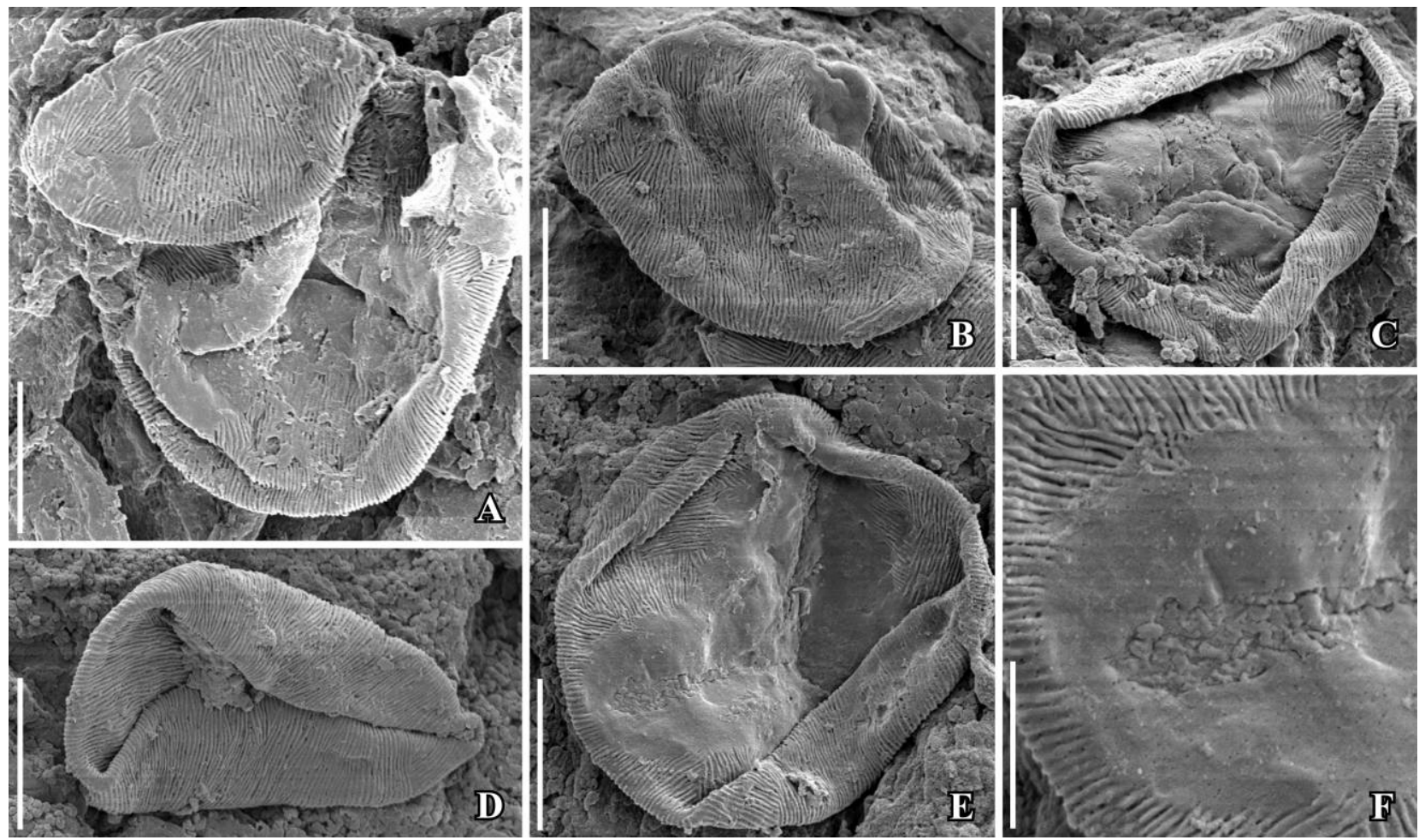

Fig. 5 SEM images of pollen grains from a flower of Saportanthus dolichostemon gen. et sp. nov. from the Early Cretaceous Vale de Água locality, Portugal. A, Folded grain showing the finely striate tectum of the proximal face partly overlaying a flattened grain that shows the distal face with a trichotomocolpate aperture surrounded by a broad psilate zone. $B$, Proximal face showing the finely striate tectum. $C$, Distal face showing a well-exposed trichotomocolpate aperture with broad psilate margin. Note the orbicules on the surface of the grain. $D$, Folded grain showing finely striate tectum. $E$, Distal face of a grain showing the distinct trichotomocolpate aperture, granular aperture membrane, and psilatepunctate aperture margin. $F$, Detail of the grain in fig. $4 E$ showing granular aperture membrane, the psilate-punctate zone surrounding the aperture, and the striate tectum in the nonapertural region. Scale bars $=5 \mu \mathrm{m}(A-E), 2 \mu \mathrm{m}(F)$.

toward the apex. Tepals are longer than, and cover, the stamens (fig. 6B, 6D, 6F).

The androecium consists of six to 10 stamens apparently in spiral arrangement (figs. $7 B, 8 B$ ). Stamens are short, about $0.3-$ $0.55 \mathrm{~mm}$ long, and up to two times longer than wide, with almost sessile, basifixed anthers. Anthers are dithecate and tetrasporangiate (fig. 6D, 6G-6I). The connective between the thecae is broad, with a single, distinct vascular bundle (figs. $7 B$, $8 B$ ), and is extended apically to a small spherical expansion (fig. $6 H, 6 I$ ). Dehiscence is latrorse to extrorse by four laterally hinged valves (fig. 6I).

Pollen grains are common in situ (fig. 9A-9I). As in $S$. dolichostemon many grains are strongly flattened, reflecting the very thin pollen wall. Typically the proximal face is exposed and the apertural region is obscured, but several grains also show the distal face. The grains are circular in equatorial outline, about $9.5-13 \mu \mathrm{m}$ in diameter. Pollen grains are typically dicolpate with two parallel colpi on the distal face (figs. 9A$9 D, 9 I, 10 A, 10 B)$. In one anther a single trichotomocolpate grain was observed among otherwise dicolpate pollen (fig. 10D). The colpi are long, extending almost to the equator (figs. 9A$9 D, 10 B)$. The distance between the colpi is about $3 \mu \mathrm{m}$. The pollen wall is very thin and is composed of a thin tectum, a thin granular infratectal layer, and a thin foot layer (fig. 9F). The tec- tum is finely striate on the proximal (nonapertural face) with fine ridges forming a fine fingerprint-like pattern, sometimes with minute pores between the ridges (fig. 9A, 9B, 9G). The granular infratectal layer is sometimes exposed in abraded grains, both in the intercolpal region (fig. $9 H, 9 I$ ) and on the proximal surface. Orbiculae are abundant in some anthers (fig. $10 A, 10 B$ ), indicating that the tapetum was secretory.

The gynoecium is composed of two (fig. $7 A-7 C$ ) or three (fig. $8 A, 8 B$ ) carpels. It is syncarpous and broadly conical above the insertion of tepals and stamens and rounded below. At the apex, the ovary has two (or three) short styles (fig. 6D). In all specimens, the ovary is bilocular or trilocular with a single ovule in each locule (figs. $7 A-7 C, 8 A, 8 B$ ). The ovules are small, api$\mathrm{cal}$, pendulous, and anatropous and do not fill the ovary cavity. The carpel wall is thick with an inner lining of narrow, longitudinally arranged sclerenchyma cells, up to about five cells deep (fig. 7B, 7C). The sclerenchyma layer is followed externally by a layer of tiny square cells that resemble crystal cells (fig. 8C). The outer carpel wall and the hypanthium wall consist of thinwalled equiaxial cells that are difficult to distinguish and are mostly filled by amorphous material. However, individual cells can be distinguished in the best-preserved specimens (fig. 8C). There is one distinct dorsal vascular bundle and two ventrallateral bundles in each carpel. The ventral-lateral bundles are 

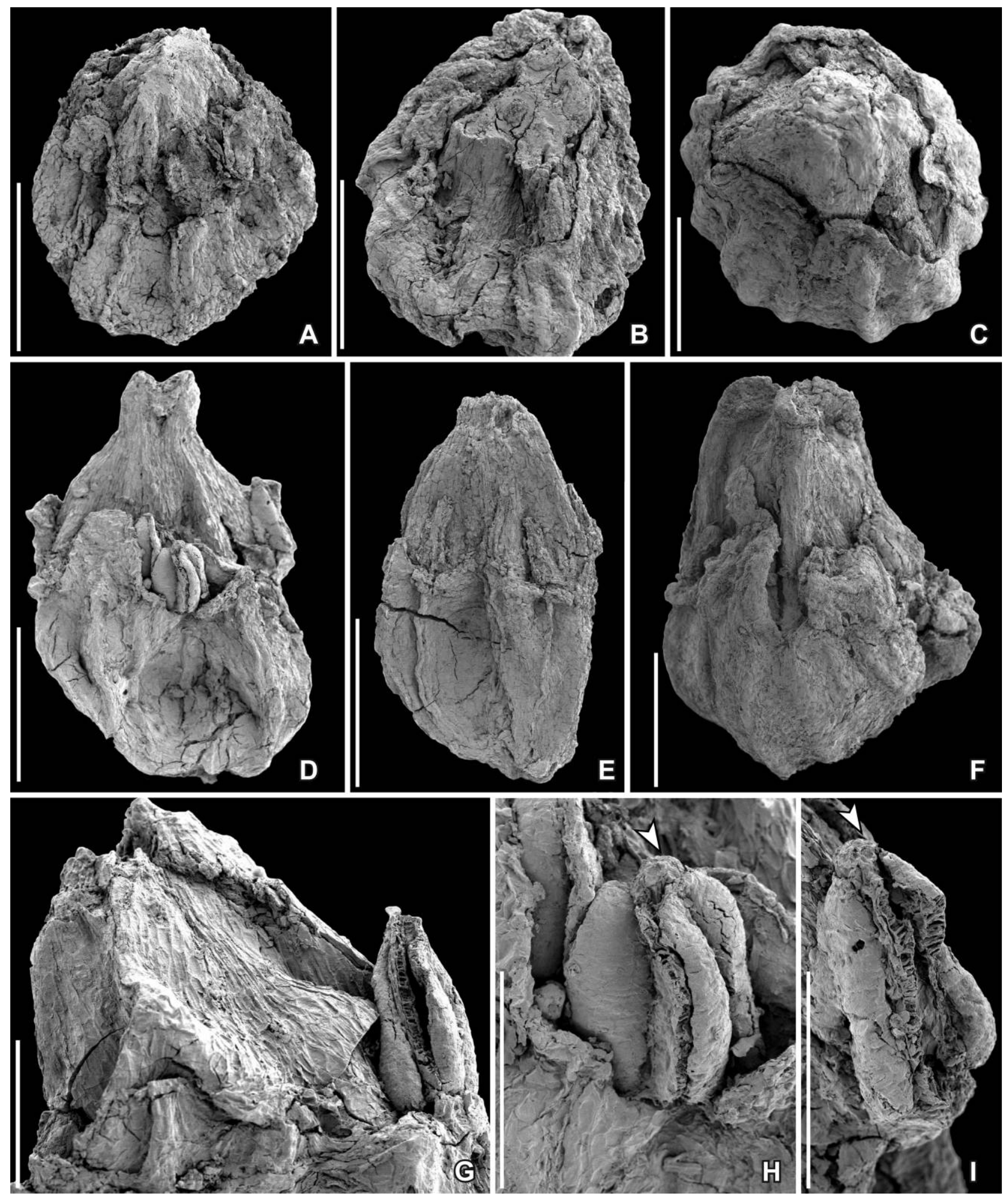

Fig. 6 SEM images of flowers of Saportanthus brachystemon gen. et sp. nov. from the Early Cretaceous Vale de Água locality, Portugal, showing flowers and fruits with triangular tepals and short stamens inserted about halfway up the semi-inferior ovary. A, Holotype; flower in oblique apical view showing remains of the perianth and short stamens around the conical upper part of the bicarpellate gynoecium (S174324, sample Vale de Água 215). B, Flower in oblique apical view showing remains of the perianth and short stamens around the broken apex of the bicarpellate gynoecium (S174334, sample Vale de Água 364). C, Fruit in apical view showing the two fused carpels and remains of tepals and stamens (see also virtual sections in fig. 7A-7C; S174163, sample Vale de Água 408). D, Flower in lateral view showing tepals and short stamens (S174775, sample Vale de Água 329). E. Flower in lateral view showing the semi-inferior ovary from which all tepals have been lost, exposing the remains of the short stamens (S174327, sample Vale de Água 141). F, Fruit in lateral view showing tricarpellate semi-inferior 

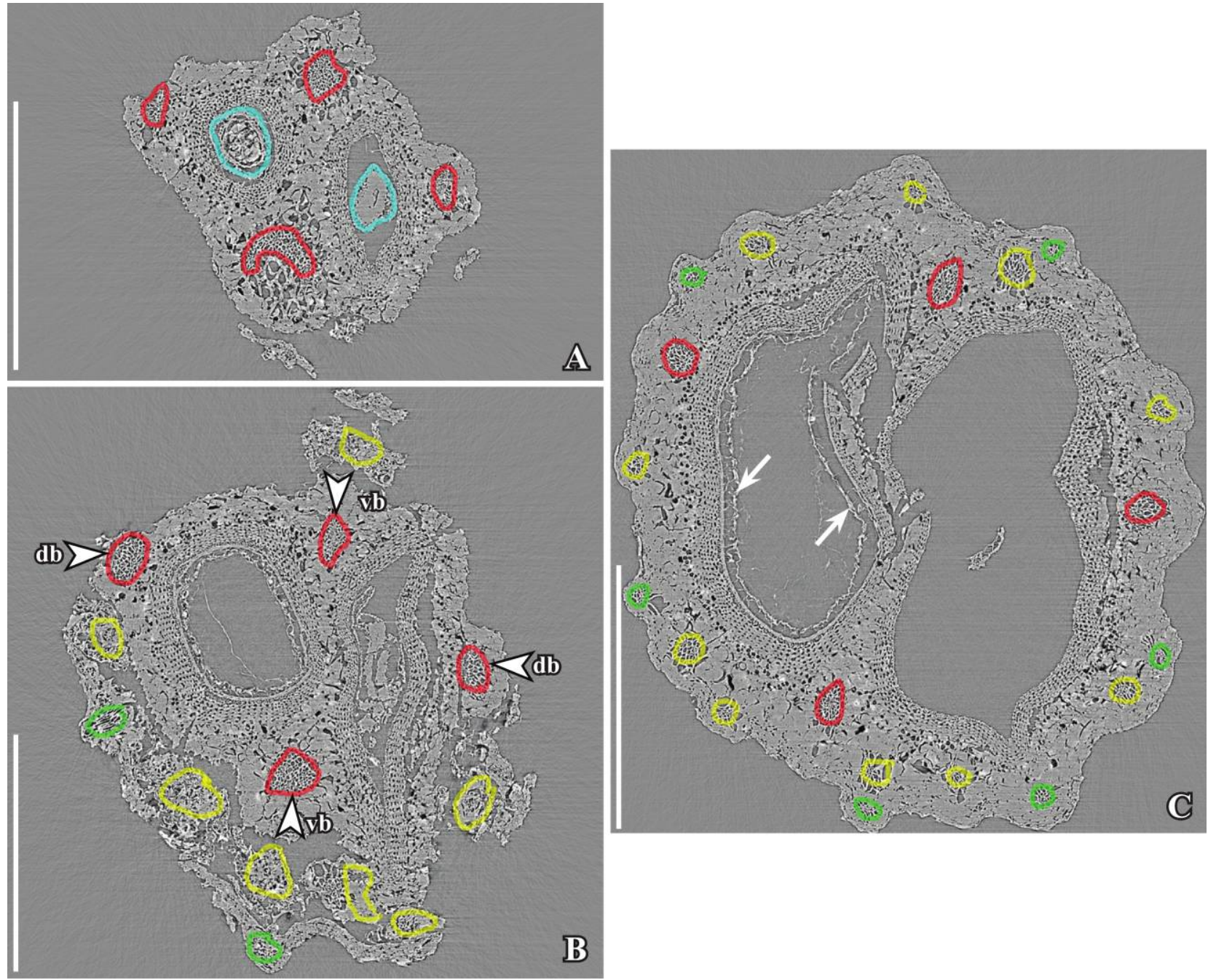

Fig. 7 Synchrotron radiation X-ray tomographic microscopy images of a bicarpellate fruit of Saportanthus brachystemon gen. et sp. nov. from the Early Cretaceous Vale de Água locality, Portugal, showing the organization of floral parts and internal structure. $A-C$, Transverse orthoslices through the specimen in fig. $6 \mathrm{C}$ in the apical part of the gynoecium (A, orthoslice xy0660), at the level of insertion of tepals and stamens $(B$, orthoslice $\mathrm{xy} 1000)$, and through the ovary below the insertion of floral parts $(C$, orthoslice xy1200). Tepals are partly abraded, but tepal bundles (green) in the fruit wall show that six tepals were present. Seven stamens are partly preserved (connectives in yellow in B), but bundles in the fruit wall show that at least 10 stamens were present (bundles in yellow in $C$ ). Dorsal $(\mathrm{db})$ and ventral (vb) bundles are both massive in the fruit wall (red, arrowheads in $B$ ). A single seed is present in each locule (blue in A). Note that one of the seeds is preserved for the full length of the locule (seed coat at arrows in C) and has nutritive tissue partly preserved (S174163, sample Vale de Água 408). Scale bars = $500 \mu \mathrm{m}$.

united on each side, broadly horseshoe shaped near the apical part of the ovary but thinner toward the base (figs. $7 A-7 C, 8 A$, $8 B$ ). The outer wall of the hypanthium is composed of thinwalled, equiaxial parenchyma cells (fig. $8 \mathrm{C}$ ). The seed wall is thin with a reticulate surface pattern. A small, straight, apparently dicotyledonous embryo is preserved in one seed (fig. 8D). The embryo is narrowly elongate, is about $200 \mu \mathrm{m}$ long, has two short cotyledons, and is surrounded by nutritive cells (endosperm). Nutritive bodies are apparently present in the endosperm except for the cells immediately surrounding the cotyledons, where the cells are empty.

Saportanthus parvus gen. et sp. nov. (Figs. 11-13)

Derivation of specific name. From the small size of the flowers (Latin parvus [small]).

Specific diagnosis. As for the genus with the following additions. Tepals six to eight, broadly ovate with rounded apices.

ovary and remains of tepals and stamens (S174173, sample Vale de Água 363). G, Apical part of the flower showing a dehisced anther with four laterally hinged valves and the short bases of other stamens (S174335, sample Vale de Água 364). H, I, Detail of the flower in D showing almost sessile anthers with valvate dehiscence and small spherical, apical extensions of the connective (arrowheads; S174775, sample Vale de Água 329). Scale bars $=500 \mu \mathrm{m}(A-F), 200 \mu \mathrm{m}(G-I)$. 

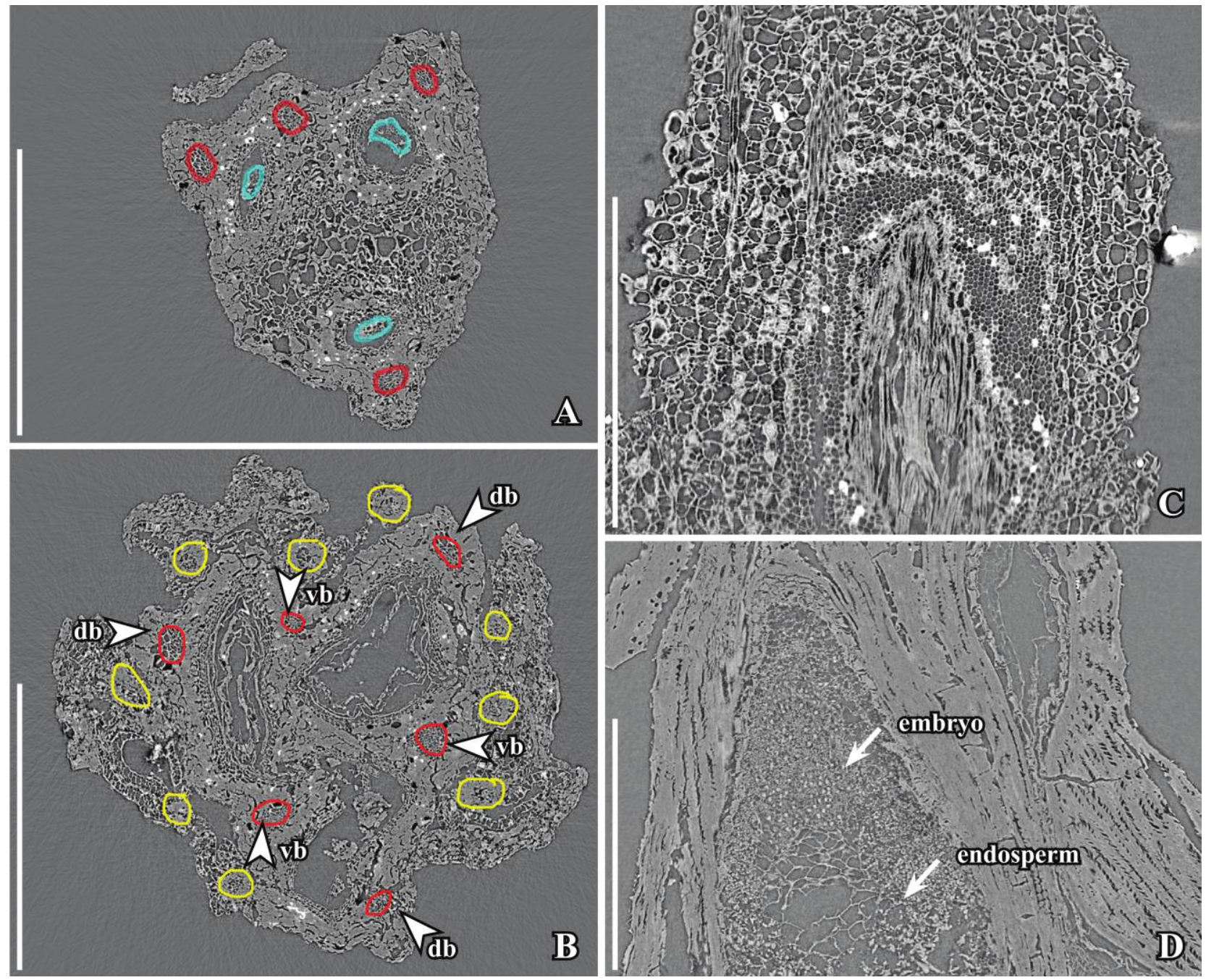

Fig. 8 Synchrotron radiation X-ray tomographic microscopy images of fruits of Saportanthus brachystemon gen. et sp. nov. from the Early Cretaceous Vale de Água locality $(A, B, D)$ and the Arazede locality $(C)$, Portugal, showing organization of floral parts and internal structure. $A, B$, Transverse orthoslices through the specimen in fig. $6 F$ in the apical part of the gynoecium $(A$, orthoslice xy0650) and at the level of insertion of tepals and stamens $(B$, orthoslice xy1050). Tepals are partly abraded, but tepal bundles in the fruit wall (not marked) indicate that six tepals were present; nine stamens are partly preserved (connectives in yellow in $B$ ). The fruit is trilocular, and both dorsal (db) and ventral (vb) bundles are massive (in red, arrowhead in B). A single seed is present in each of the three locules (blue in A; S174173, sample Vale de Água 363). $C$, Longitudinal orthoslice (yz0270) through rare charcoalified fruit and hypanthium wall showing (from the inside outward) elongate sclerenchyma of the inner layer, tiny square cells, and thin-walled parenchyma cells of the outer fruit wall and hypanthium (S174357, sample Arazede 374). D, Longitudinal orthoslice (yz0955) of fruit with a small, straight embryo and remains of nutritious tissue (endosperm; S174436, Vale de Água 328). Scale bars $=500 \mu \mathrm{m}(A-C), 250 \mu \mathrm{m}(D)$.

Stamens five to seven, $0.5 \mathrm{~mm}$ long and about two times longer than wide. Pollen dicolpate? Ovary unicarpellate. Carpel wall thick. Upper part of ovary wall with short trichomes. Floral tissue with oil cells.

Distinguishing features. See "Discussion."

Holotype. S174301 (sample Catefica 242), designated here (figs. 11A, 12A, 12C-12F).

Paratypes. S100757, S100758, S107752-S107755, S107775-S107777, S174318-S174320, S174785, S174829S174831 (sample Catefica 49), S170434, S170435, S174832 (sample Catefica 50), S174315-S174317 (sample Catefica 152), S101292, S101293 (sample Catefica 154), S174301, S174833 (sample Catefica 242), S122088 (sample Catefica 342), S174356 (sample Catefica 360), S174321, S174322, S174834, S174835 (sample Catefica 361).

Type locality. Catefica $\left(39^{\circ} 03^{\prime} 30^{\prime \prime} \mathrm{N}, 09^{\circ} 14^{\prime} 30^{\prime \prime} \mathrm{W}\right)$, between the villages of Catefica and Mugideira, about $4 \mathrm{~km}$ south of Torres Vedras, Portugal.

Type horizon and age. Almargem Formation, Early Cretaceous (late Barremian-early Albian).

Description of Saportanthus parvus. The new species is based on 31 fossil flowers, all from the Catefica locality. A single flower that is very similar to $S$. parvus from Catefica has also been reported from the Chicalhão site near Juncal, Portugal, as flower 2 (pl. III, fig. 2, in Mendes et al. 2014), but details of this specimen are unknown, and conspecificity with the speci- 

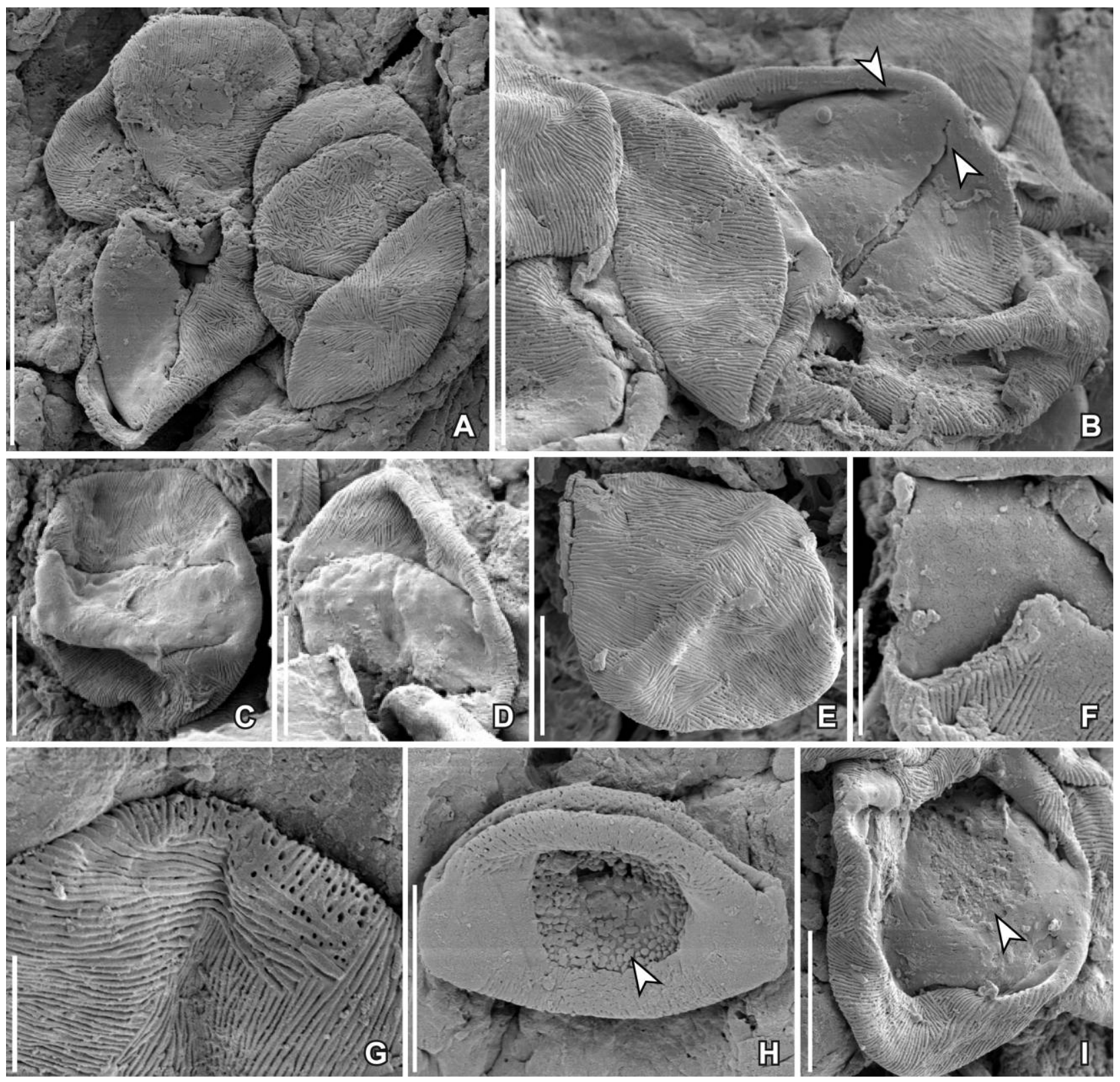

Fig. 9 SEM images of pollen from a flower of Saportanthus brachystemon gen. et sp. nov. from the Early Cretaceous Vale de Água locality, Portugal. A, Group of pollen grains from the anther of the flower in fig. $6 B$. Note that most grains expose the finely striate tectum of the proximal surface but that one grain (partly split along the colpi) exposes the distal surface and shows two colpi separated by a broad intercolpium with a psilate tectum (S174334, sample Vale de Agua 364). B, Pollen grains from anther of the flower in fig. 6A (holotype). Note that one grain shows the two colpi (arrowheads) and the broad psilate region between and bordering the colpi (S174324, sample Vale de Água 215). C, D, Two grains from the flower in fig. 6B exposing the distal surface (S174334, sample Vale de Água 364). E, Proximal view of pollen from the specimen in fig. 6C showing finely striate tectum (S174163, sample Vale de Água 408). F, Broken pollen grain from the flower in fig. $6 B$ showing very thin pollen wall with a finely striate tectum, a thin granular infratectal layer, and a thin footlayer (S174334, sample Vale de Água 364). G, Detail of pollen wall showing striations forming a fingerprint-like pattern. Note the perforations between ridges (S174324, Vale de Água 215). H, Pollen grain from the flower in fig. $6 \mathrm{~B}$ showing abraded distal surface exposing granular infratectal layer (arrowhead; S174334, sample Vale de Água 364). I, Pollen grain from the flower in fig. 6A (holotype) showing abraded distal surface exposing granular infratectal layer (arrowhead; S174324, sample Vale de Água 215). Scale bars $=10 \mu \mathrm{m}(A, B), 5 \mu \mathrm{m}(C-E, H, I), 2 \mu \mathrm{m}(F, G)$.

mens from Catefica is uncertain. More than 20 flowers were studied using SEM, and four specimens were analyzed using SRXTM. The specimens often have tepals and stamens intact, and many flowers have pollen grains in situ. In most cases the gy- noecium is compressed, and details of internal features are generally not as well preserved as in S. dolichistemon and S. brachystemon. All flowers occur isolated, and there is no information about how the flowers were borne on the plant. 

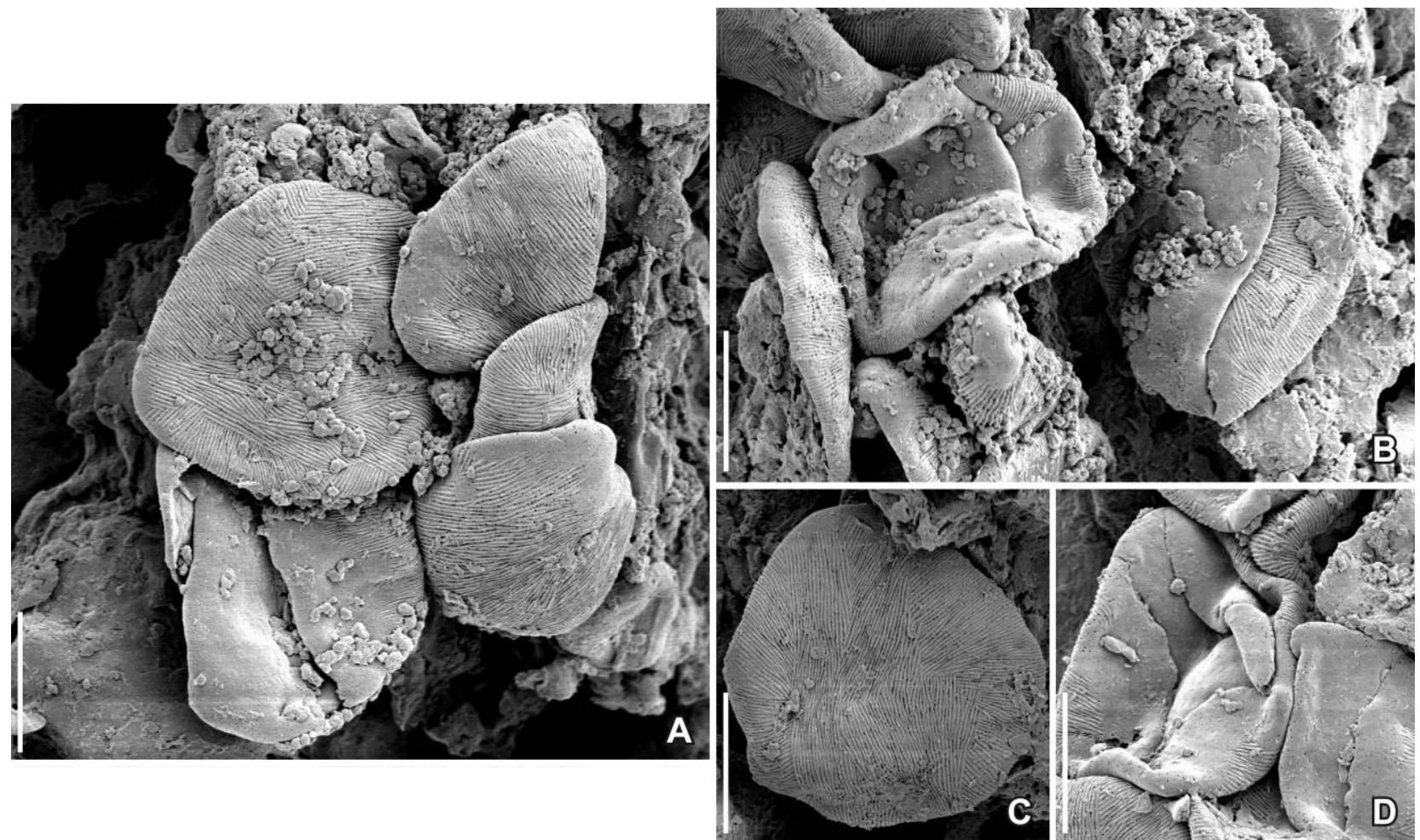

Fig. 10 SEM images of pollen from a flower of Saportanthus brachystemon gen. et sp. nov. from the Early Cretaceous Vale de Água locality, Portugal (same flower as in fig. 6E; S174327, sample Vale de Água 141). A, B, Group of pollen grains showing proximal surfaces with fingerprint-like striations and distal surfaces with psilate zones associated with the colpi. Note that all grains in which the apertures can be seen have two colpi and that orbicules are scattered over the surface of the grains and the inner surface of the pollen sacs. C, Proximal surface of grain showing fingerprint-like striations. $D$, Two pollen grains in the same pollen sac, one with trichotomocolpate and one with dicolpate aperture configurations. Scale bars $=5 \mu \mathrm{m}$.

Flowers are about $0.9-1.4 \mathrm{~mm}$ long, $0.8-1.2 \mathrm{~mm}$ in diameter, and structurally bisexual (figs. $11 C-11 G, 12 A-12 F$ ). The ovary is semi-inferior, with tepals and stamens inserted about halfway up the ovary. The perianth consists of six to eight undifferentiated, broadly rounded tepals, with a rounded apex and broad attachment (figs. $11 A-11 C, 11 E, 11 F, 12 A, 12 B$ ). Tepals are in two series and are apparently spiral in arrangement, although this is not completely clear. A large, median vascular bundle is present near the base of the tepal, and distally there are two or more lateral bundles (fig. 12C). Tepals are about the same length as the stamens (fig. 11A-11E).

The androecium consists of five to six stamens apparently spirally arranged (figs. $11 E, 12 A, 12 C, 12 D$ ). Stamens are short, about $0.5 \mathrm{~mm}$, and are about two times longer than wide, with almost sessile and basifixed anthers. The anthers are dithecate and tetrasporangiate (figs. $11 C, 11 E, 12 C$ ). The connective between the thecae is broad, with a single, distinct vascular bundle (fig. 12C, 12D). Each connective has a dome-shaped apical expansion (figs. 11C, 11E, 12A, 12B). Dehiscence is latrorse to extrorse by four laterally hinged valves (fig. 11C).

Pollen grains occur commonly in situ (fig. 13A-13C), but in all cases they are folded or show only the proximal face. There are no well-exposed apertures, but in a few cases where the distal face is partly visible, the grains appear dicolpate (fig. 13B). Pollen grains are closely similar to those of $S$. dolichostemon and S. brachystemon in size, exine structure, and surface orna- mentation, with a thin pollen wall and finely striate fingerprintlike ornamentation of the tectum. Pollen grains are circular in equatorial outline, about $8-11 \mu \mathrm{m}$ in diameter.

The gynoecium is apparently composed of one or possibly two carpels. It is broadly conical above the insertion of tepals and stamens and obconical below, with a base that is pointed or slightly rounded (fig. $11 A-11 D, 11 F$ ). The carpel wall above the insertion of tepals and stamens has an indumentum of short, stiff trichomes. At the apex the ovary has one style that terminates in a small stigmatic area (figs. $11 E, 12 A, 12 B$ ). The ovary is usually much compressed, but one well-preserved specimen studied using SRXTM shows a single locule with a single small apical and pendulous, anatropous ovule that does not fill out the ovary cavity (fig. 12E, 12F). The carpel wall is thick, with an inner lining of narrow, longitudinally arranged sclerenchyma cells. Other tissues of the carpel wall and carpel bundles are not well preserved.

Spherical hollow spaces, which we interpret as the remains of ethereal oil cells, occur in the floral tissue of some specimens (figs. 11C, 11E, 12F).

\section{Phylogenetic Analyses and Scoring of Characters}

To assess the phylogenetic position of Saportanthus among extant angiosperms, characters of the fossil flowers were scored according to the morphological data set developed by Doyle 
and Endress (Doyle and Endress 2000, 2010, 2014; Endress and Doyle 2009, 2015) for extant angiosperms, which includes the earliest diverging extant lineages as well as eumagnoliids and placeholders for monocots and eudicots. Fifty-nine reproductive characters were scored for Saportanthus as below, with the characters and numbers after Doyle and Endress (2014): 47, sex of flowers - bisexual; 48, floral base - partially or completely inferior ovary; 49, floral receptacle, female portion-short; 50, pits in receptacle bearing individual carpels - absent; 52, floral apex - used up after production of carpels; 53, perianth - present; 54, perianth phyllotaxis — spiral; 55, perianth merism- polymerous; 56, perianth whorls/series - two; 57 , tepal differentiation-all more or less sepaloid; 58, petals - absent; 59, nectaries on inner perianth parts - absent; 60, outermost perianth partsfree; 61, calyptra derived from last one or two bracteate organs below the flower-absent; 62, stamen number-more than one; 63, androecium phyllotaxis - spiral; 64, androecium merismpolymerous; 65 , number of stamen whorls/series - two; 66 , stamen positions - single; 67 , stamen fusion-free; 68 , inner staminodes-absent; 69, glandular food bodies on stamens or staminodes_absent; 70, stamen base-short; 71, paired basal stamen glands - absent; 72, connective apex - truncate or smoothly rounded; 73, pollen sacs - protruding; 74, microsporangiafour; 75 , orientation of dehiscence - extrorse (dehiscence in the fossil is latrorse to extrorse, but alternative scoring would be latrorse-introrse); 76, mode of dehiscence- $\mathrm{H}$-valvate; 77, connective hypodermis - unspecialized; 81, pollen units - monads; 82, pollen size - small $(<20 \mu \mathrm{m}) ; 83$, pollen shape - globose; 84; aperture type - polar/sulculate; 85 , distal aperture shape - elongate; 86 , distal aperture branching-unbranched/with several branches; 87 , infratectum-granular; 88 , tectum-continuous or microperforate; 90 , striate muri-absent; 91, supratectal spinules-absent; 92, prominent spines-absent; 93, aperture membrane-sculptured; 95, nexine thickness - thin but continuous; 96, carpel number - two to five in one whorl/series (one for $S$. parvus); 98, postgenital sealing of carpel-complete; 101, style-present; 102, stigma-restricted; 107, oil cells in carpels - absent or internal; 108, long unicellular hairs on and/ or between carpels - absent; 109, short curved appressed unlignified hairs with up to two short basal cells and one long apical cell on carpels - absent; 110, nectary on dorsal or lateral sides of carpel or pistillode-absent; 111, septal nectaries or potentially homologous basal intercarpellary nectaries-absent; 112 , number of ovules per carpel—one; 113 , placentation — ventral; 114, ovule direction-pendent; 115, ovule curvatureanatropous (or nearly so); 123, fruit wall-wholly or partly fleshy; 124, lignified endocarp - present; 125, fruit dehiscenceindehiscent or dehiscing irregularly dorsal only or laterally; 126, hooked hairs on fruit-absent.

Analyses that included two other fossil taxa, Lovellea (Dettmann et al. 2009) and Jamesrosea (Crepet et al. 2016), were also performed on the same data set. Fifty characters were scored for Lovellea on the basis of information in Dettmann et al. (2009): 47, sex of flowers - bisexual; 48, floral base-hypanthium present, superior ovary; 49 , floral receptacle, female portion - short; 52, floral apex-used up after production of carpels; 53, perianth - present; 54, perianth phyllotaxis - spiral; 55, perianth merism - polymerous; 56 , perianth whorls/series - two; 57, tepal differentiation-all more or less sepaloid; 58 , petals - absent; 59, nectaries on inner perianth parts-ab- sent; 60 , outermost perianth parts-free; 62 , stamen numbermore than one; 63, androecium phyllotaxis - spiral; 64, androecium merism-polymerous; 65 , number of stamen whorls/series - two; 66, stamen positions - single; 67, stamen fusionfree; 68, inner staminodes-absent; 69, glandular food bodies on stamens or staminodes - absent; 70, stamen base-long and wide; 71, paired basal stamen glands-absent; 73, pollen sacsprotruding; 74, microsporangia-two; 75 , orientation of dehiscence-distinctly introrse; 81 , pollen units-monads; 82, pollen size - medium $(20-50 \mu \mathrm{m}) ; 84$, aperture type - polar/sulculate; 85 , distal aperture shape-elongate; 86 , distal aperture branching - unbranched; 95, nexine thickness - thin but continuous; 96, carpel number-more than one whorl/series; 101, style - present; 106, carpel fusion-apocarps; 107, oil cells in carpels_absent or internal; 108, long unicellular hairs on and/ or between carpels-present; 109, short curved appressed unlignified hairs with up to two short basal cells and one long apical cell on carpels-absent; 110, nectary on dorsal or lateral sides of carpel or pistillode - absent; 111, septal nectaries or potentially homologous basal intercarpellary nectaries - absent; 112, number of ovules per carpel —one; 113 , placentation - ventral; 114, ovule direction - ascendent; 115, ovule curvatureanatropous (or nearly so); 116, integuments - two; 119 , outer integument thickness - two cells; 121 , chalaza-pachychalazal; 123, fruit wall - wholly or partly fleshy; 124 , lignified endocarp-present; 125, fruit dehiscence-indehiscent or dehiscing irregularly dorsal only or laterally; 126 , hooked hairs on fruitabsent.

Twenty-nine characters were scored for Jamesrosea on the basis of information in Crepet et al. (2016): 47, sex of flowers-bisexual; 48, floral base-hypanthium present, superior ovary; 49, floral receptacle, female portion-short; 52, floral apex-used up after production of carpels; 53, perianth-present; 55, perianth merism-polymerous; 57 , tepal differentiation-all more or less sepaloid; 58, petals-absent; 60, outermost perianth parts - free; 62, stamen number-more than one; 63 , androecium phyllotaxis - spiral; 64, androecium merismpolymerous; 66 , stamen positions - single; 67 , stamen fusionfree; 68, inner staminodes - present; 69, glandular food bodies on stamens or staminodes - absent; 70, stamen base-long and narrow; 71, paired basal stamen glands-present; 73, pollen sacs - embedded; 74, microsporangia-two; 75, orientation of dehiscence-distinctly introrse/extrorse; 76, mode of dehiscence-valvate with upward-opening flaps; 96, carpel number-more than one whorl/series; 101, style - present; 106, carpel fusion-apocarpous; 110, nectary on dorsal or lateral sides of carpel or pistillode-absent; 111, septal nectaries or potentially homologous basal intercarpellary nectaries - absent; 112, number of ovules per carpel — one; 113, placentation — ventral.

We also assessed the phylogenetic position of Saportanthus using the data set for Laurales developed by Renner (1999), scoring the characters as follows: 1, phyllotaxis-alternate or spiral alternate; 2, cup-shaped receptacle-present; 3, innermost tepals - free; 4, fixed stamen numbers - absent; 5, paired glands on filament bases-absent; 6, anther dehiscence-longitudinal; 7 , apertures-meridionosulcate or disulcate; 8 , carpels - several; 9, epigyny - present; 11, ovule number and position - one apical; 13, fruit type - drupe.

Using the character scorings given above, we evaluated the relationships of Saportanthus and the other fossils by linking 

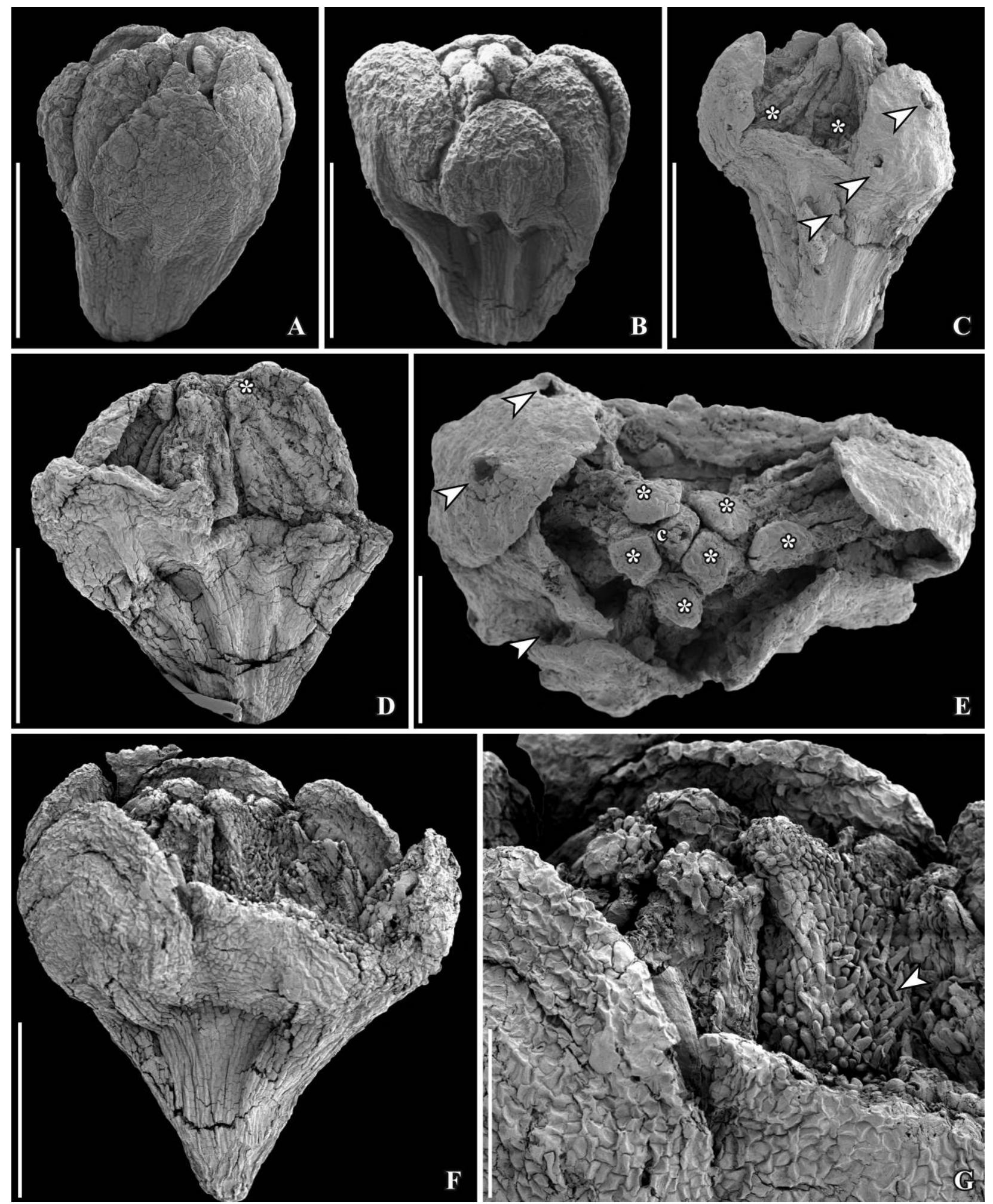

Fig. 11 SEM images of flowers of Saportanthus parvus gen. et sp. nov. from the Early Cretaceous Catefica locality, Portugal, showing flowers with broad, rounded tepals and elongated stamens that are inserted about halfway up the semi-inferior ovary. A, Holotype; flower in lateral view showing six broad tepals with rounded apices concealing the partially protruding stamens (S174301, sample Catefica 242). B, Flower in lateral view showing rounded tepals (six visible on rotating the specimen) surrounding the dome-shaped apical extensions of the connectives of several stamens (S107775, sample Catefica 49). C, Flower in lateral view showing tepals, one of which is broken, revealing the elongated stamens with almost sessile anthers (asterisks). Note the small circular openings in the epidermis (arrowheads) that are inferred to be burst oil cells (S122088, sample Catefica 243). D, Flower in lateral view with several tepals abraded, exposing stamens that each have a dome-shaped apical 
the fossils to all branches of a backbone topology. In the case of the Doyle and Endress data set, we used the result from a combined analysis of molecular and morphological data as the backbone topology (see, e.g., fig. 3 in Endress and Doyle 2015). We also experimented with assessing the relationships of $\mathrm{Sa}$ portanthus using both the full data set (all taxa included) and a subset that included only Laurales with Liriodendron and Magnolioideae as outgroups. In the case of the Renner data set, we used the strict consensus tree resulting from Renner's analysis (1999). For each position, we assessed tree length by recalculating the number of required character state changes under parsimony using Mesquite software (ver. 3.2; Maddison and Maddison 2017).

\section{Discussion}

The fossil flowers described here are assigned to a new genus, Saportanthus, characterized by a combination of features that is unknown among extant or extinct angiosperm flowers. Flowers are small, with an undifferentiated perianth and a variable number of tepals and stamens. Anthers are basifixed, almost sessile, and dehisce by four laterally hinged valves. The valvate dehiscence is probably correlated with the extensive connective, as described for several extant magnoliid angiosperms (Endress and Hufford 1989), including Sinocalycanthus (Staedler et al. 2007). The distinctive pollen grains are dicolpate or trichotomocolpate, with a very thin pollen wall and finely striate exine ornamentation that results in a fingerprint-like pattern on the proximal face. Around the aperture on the distal face the exine ornamentation is psilate-punctate. The syncarpous semi-inferior ovary comprises one (perhaps two) carpels in Saportanthus parvus and two to three carpels in Saportanthus dolichostemon and Saportanthus brachystemon. In all three species, there is a single apical, pendulous, and anatropous ovule in each carpel.

On the basis of details of perianth and stamen morphology, number of floral parts, and carpel anatomy (vasculature and wall structure) as well as the pollen apertures, three distinct species are recognized. Saportanthus dolichostemon is characterized by elongate triangular tepals, elongate stamens, and trichotomocolpate pollen. Saportanthus brachystemon is characterized by broadly triangular tepals, short stamens, and predominantly dicolpate pollen. Saportanthus parvus has rounded tepals, long stamens, and apparently dicolpate pollen. The valvate anther dehiscence together with the small pollen sacs strongly indicate insect pollination for all three species.

The flowers of Saportanthus formally described and named here have been illustrated in earlier reports on the mesofossil floras of Portugal (Friis et al. 1994b, 2000, 2011), but their affinity remained uncertain because of their unusual combination of characters. Some features indicated a relationship with monocots, while other features suggested a position among earlydiverging angiosperms and eumagnoliids. A more detailed and more satisfactory systematic assessment was possible only when important internal features and a better understanding of the irregular floral organization were revealed by SRXTM.

In an early study (Friis et al. 1994b), a flower of S. dolichostemon from the Vale de Água locality was reported as possible Laurales (Friis et al. 1994b) and described as epigynous and octomerous (Friis et al. 2000). SRXTM revealed that this specimen has eight tepals but 10 stamens, while other specimens assigned to the same species have six or seven tepals and an androecium in which the number of stamens varies from 10 to at least 15 . Similarly, S. parvus from the Catefica locality was described as epigynous and trimerous and was reported as of unknown affinity but perhaps related to monocots (Friis et al. 2011). Examination of more material as well as SRXTM analyses have shown that $S$. parvus is not regularly trimerous and that flowers with two series of three tepals may have only five stamens. Other flowers of $S$. parvus have seven or eight tepals, and phyllotaxis is apparently spiral rather than whorled.

\section{Comparison with Extant Angiosperms}

In assessing the phylogenetic position of Saportanthus, the pollen grains proved particularly puzzling despite their distinctive form. Trichotomocolpate (trichotomosulcate) grains occur scattered among basal grade angiosperms (Cabombaceae, Hydatellaceae, and Chloranthaceae), eumagnoliid angiosperms (Annonaceae, Canellaceae, Piperaceae, Saururaceae, and Winteraceae), and monocots (e.g., Arecaceae, Cyperaceae, Hemerocallidaceae, Liliaceae, and Rapateaceae; Wilson 1964; Walker 1974; Furness and Rudall 1999; Furness et al. 2002; Nadot et al. 2006; Remizowa et al. 2008). Similarly, dicolpate (disulcate, disulculate, and pantoperculate/operculate) pollen grains are also reported in ANA-grade angiosperms (Trimeniaceae), eumagnoliids (Annonaceae, Calycanthaceae), and monocots (e.g., Arecaceae, Colchicaceae, Dioscoreaceae, Hypoxidaceae, Liliaceae, Orchidaceae, Pontederiaceae, Rapateaceae, Tofieldiaceae, and Velloziaceae; Walker 1974; Zavada 1983; Sampson and Endress 1984; Sampson 1987; Waha and Morawetz 1988; Harley 1996; Furness and Rudall 1999, 2003; Rudall 2002; Furness et al. 2015). However, the occurrence of both dicolpate and trichotomocolpate pollen in the same group of closely related taxa is unusual, and to our knowledge it is reported only in the eumagnoliid family Annonaceae (Furness et al. 2002) and in a few monocot families, such as Arecaceae (Arecoideae, Coryphoideae), Liliaceae, and Rapateaceae (Zavada 1983; Harley 1996; Furness and Rudall 1999).

The pollen wall in Saportanthus, with its very thin exine, finely striate, fingerprint-like ornamentation on the proximal face and psilate-punctate ornamentation on the distal face, is also unusual. Among ANA-grade angiosperms, trichotomocolpate grains with similar ornamentation occur in Cabomba (Remizowa et al. 2008; Taylor et al. 2008), but in Cabomba the striate exine ornamentation consists of thinner and thicker ridges, and there is no differentiation in ornamentation between the proximal and

extension of the connective (asterisk for one stamen; S174114, sample Catefca 49). E, Flower in C in apical view showing six tepals, six stamens with anthers that each have a dome-shaped apical extension of the connective (asterisks), and a single style (c); note that anthers dehisce by laterally hinged valves and the small circular openings in the epidermis (arrowheads) that are inferred to be burst oil cells. F, Flower in lateral view showing rounded tepals and obconical ovary below the insertion of tepals and stamens. Note that one tepal is broken, revealing the stamens and apical part of gynoecium (S174320, sample Catefica 49). G, Detail of the flower in $F$ showing apical region of gynoecium with short, stiff trichomes (arrowhead). Scale bars $=500 \mu \mathrm{m}(A-D, F), 200 \mu \mathrm{m}(E, G)$. 

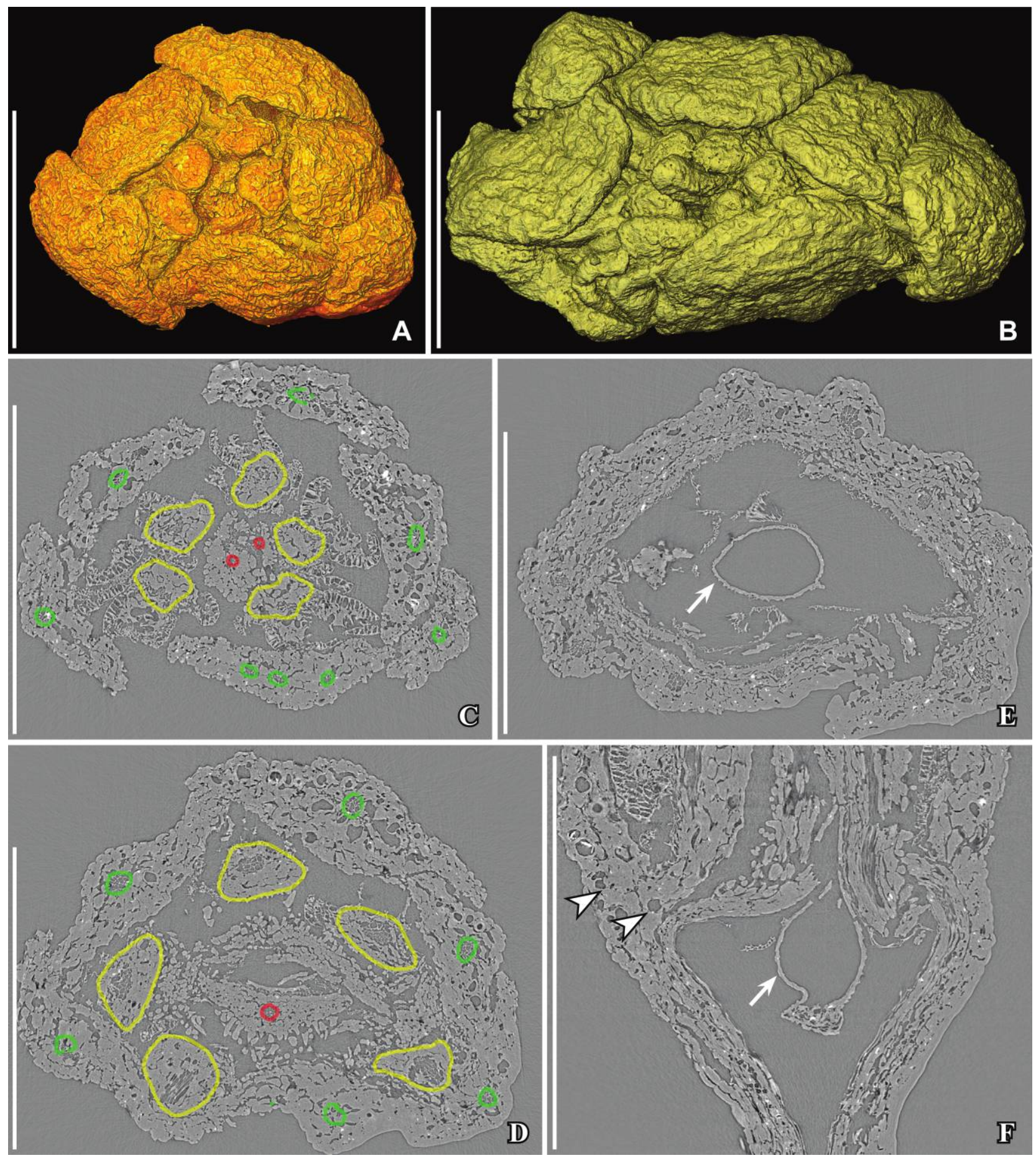

Fig. 12 Synchrotron radiation X-ray tomographic microscopy images of flowers of Saportanthus parvus gen. et sp. nov. from the Early Cretaceous Catefica locality, Portugal, showing external form $(A, B)$ and internal structure $(C-F)$. A, Holotype; volume rendering of a flower in apical view showing six tepals and five stamens (S174301, sample Catefica 242). B, Volume rendering of a flower in apical view showing seven tepals and several stamens (six or seven seen in virtual sections, not shown here; S100754, sample Catefica 49). C-E, Transverse orthoslices of the flower shown in figs. $11 \mathrm{~A}$ and $12 \mathrm{~A}$ (holotype) at the level of the perianth and androecium (C, orthoslice xy0500), at the level of the insertion of tepals and stamens $(D$, orthoslice xy1300), and below the insertion of tepals and stamens (E, orthoslice xy1650), showing six tepals (tepal bundles, green), five stamens (connectives, yellow), two carpels (carpel bundles, red), and a single locule with a single ovule (arrow). $F$, Longitudinal orthoslice through the central part of the flower shown in figs. $11 \mathrm{~A}$ and $12 \mathrm{~A}$ (holotype) showing the single locule with a single, apical, and pendulous ovule (arrow). Note the spherical spaces in floral tissue (arrowheads) that are interpreted as remains of ethereal oil cells. Scale bars $=500 \mu \mathrm{m}$. 

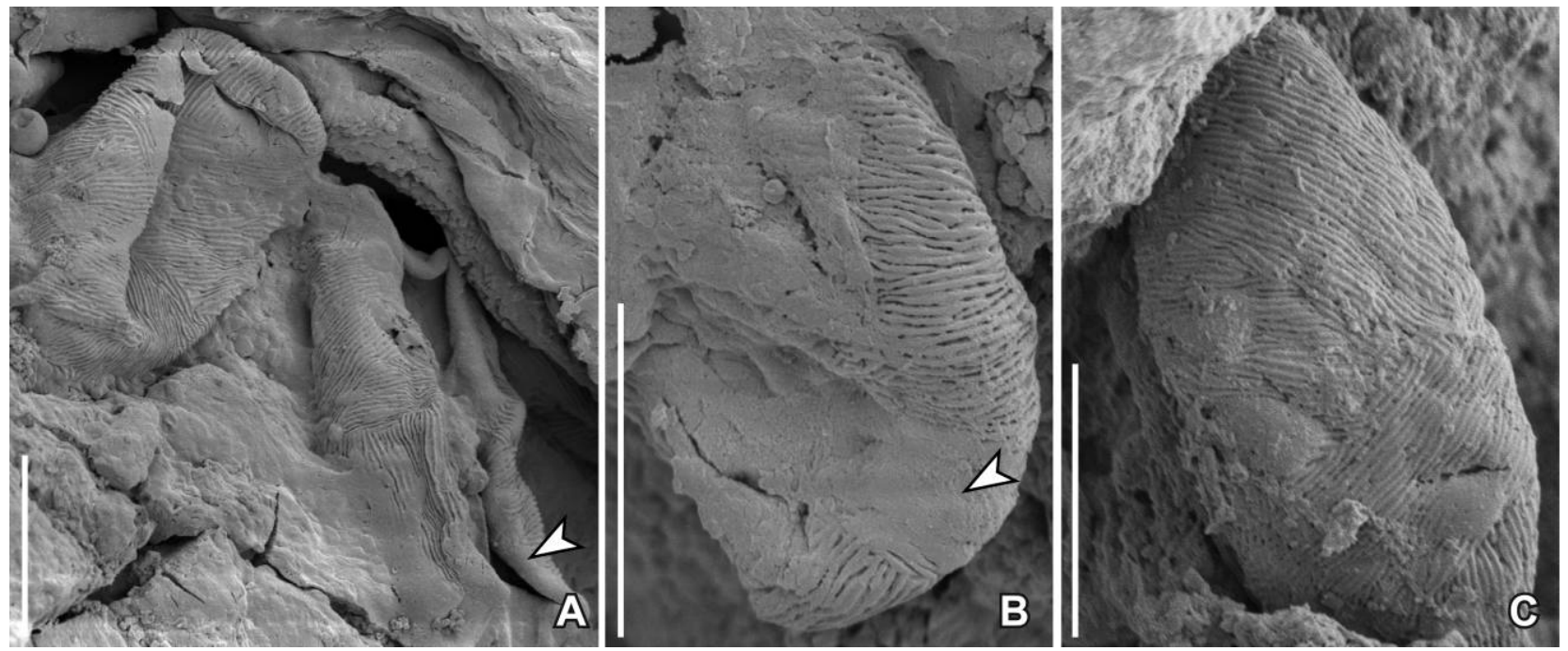

Fig. 13 SEM images of pollen from flowers of Saportanthus parvus gen. et sp. nov. from the Early Cretaceous Catefica locality, Portugal. $A-C$, Poorly preserved pollen grains from two different flowers showing finely striate fingerprint-like exine sculpturing of the tectum over most of the grain surface and the psilate zone in the apertural region (arrowhead); in none of the grains is the aperture fully exposed $(A, \mathrm{~S} 174035$, sample Catefica 50; B, C, S174317, sample Catefica 152). Scale bars $=500 \mu \mathrm{m}$.

distal faces. Among monocots, striate exine ornamentation resembling that of Saportanthus is reported for dicolpate grains of Dioscorea (Wilkin et al. 2000; Schols et al. 2001, 2003; Wilkin et al. 2009). However, in Dioscorea the striate ornamentation is coarser than in Saportanthus, and again there is no differentiation of the exine ornamentation between the proximal and distal face.

Our comparisons of flowers of Saportanthus to extant angiosperms producing trichotomocolpate or dicolpate pollen did not result in any close match. We therefore conducted a broader literature search among ANA-grade angiosperms, eumagnoliids, and monocots and found that several unusual floral features of Saportanthus closely match features seen in some extant Laurales, as was anticipated in a very preliminary account of the fossil flowers (Friis et al. 1994b).

Among the seven families of extant Laurales (Atherospermataceae, Calycanthaceae [including Idiospermataceae], Gomortegaceae, Hernandiaceae, Lauraceae, Monimiaceae, and Siparunaceae; Renner 1999), flowers of extant Gomortega keule, the single living species of Gomortegaceae, which is known only from a very restricted area of the Cordillera de la Costa in southern Chile (Kubitzki 1993), are especially similar to those of $S a$ portanthus. Like Saportanthus, flowers of Gomortega are bisexual with an irregular number of floral parts arranged helically around a syncarpous, (semi)-inferior gynoecium that consists of two or three carpels with short, stout styles. In addition, in both Gomortega and Saportanthus each carpel contains one apical and pendulous ovule, and the gynoecium develops into a drupaceous fruit with a single seed (Buchheim 1958; Brizicky and Buchheim 1959; Leinfellner 1968; Kubitzki 1993; Staedler and Endress 2009). The embryo in both taxa is also small and straight (Doweld 2001). Hesse and Kubitzki (1983) also describe the pollen grains of Gomortega as having a thin, continuous exine, as in Saportanthus.
Nevertheless, despite these similarities there are also differences between Gomortega and Saportanthus. Stamens in Gomortega have paired staminal glands (not present in Saportanthus), anthers are bisporangiate (tetrasporangiate in Saportanthus), and anther dehiscence is by two apically hinged valves (four laterally hinged valves in Saportanthus). In addition, pollen of Gomortega is inaperturate with finely spinulate exine sculpture (dicolpate-trichotomocolpate with finely striate to psilatepunctate in Saportanthus; Buchheim 1958; Brizicky and Buchheim 1959; Leinfellner 1968; Hesse and Kubitzki 1983; Kubitzki 1993; Staedler and Endress 2009).

Among the differences from Gomortega, the occurrence of four laterally hinged valves in Saportanthus is especially interesting. Very similar valvate dehiscence occurs in Sinocalycanthus (Calycanthaceae; not included in the Doyle and Endress matrix), while all other members of the Calycanthaceae have anther dehiscence by longitudinal slits (Staedler et al. 2007). Staedler et al. (2007) suggest that the valvate dehiscence in Sinocalycanthus is correlated with the extensive development of the connective in that genus, as described for several other extant ANA-grade and magnoliid angiosperms (Endress and Hufford 1989).

\section{Phylogenetic Analyses}

We tested the validity of a putative relationship to extant Laurales by including Saportanthus in the morphological data matrix developed by Doyle and Endress (Doyle and Endress 2000, 2010, 2014; Endress and Doyle 2009, 2015) for earlydiverging angiosperms, including ANA-grade lineages, Ceratophyllum, Chloranthaceae, eumagnoliids, monocots, and earlydiverging eudicots, using both the full data set and a subset restricted to Laurales with Liriodendron and Magnolioideae as outgroups. We also examined the position of Saportanthus 

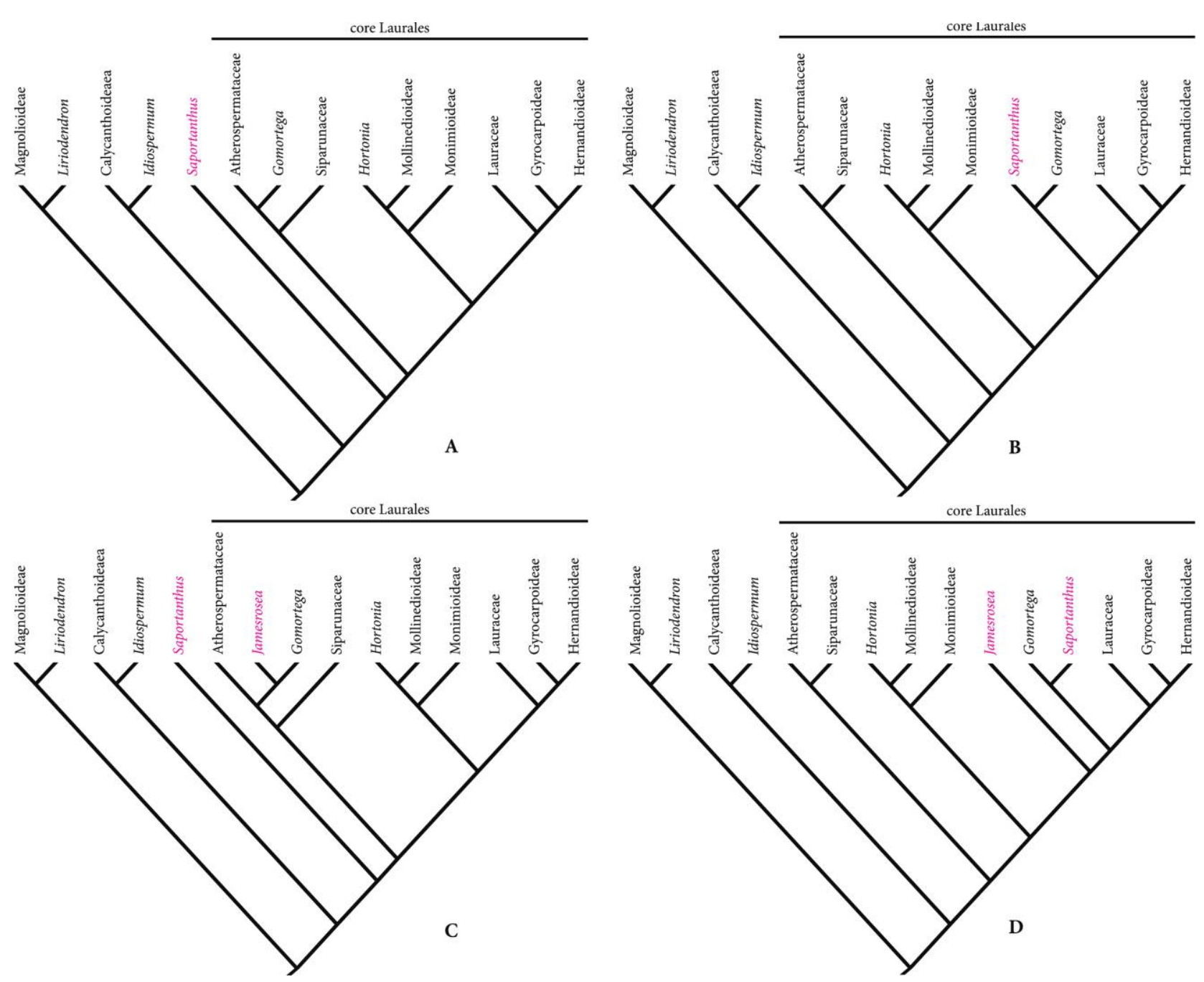

Fig. 14 Various positions of the fossil flowers Saportanthus and Jamesrosea added to the combined molecular-morphological backbone tree of Endress and Doyle (2015) for extant Laurales with Liriodendron and Magnolioideae as outgroups. A, Most parsimonious position (184 steps) of Saportanthus in the fixed backbone tree. B, One of four most parsimonious positions of Saportanthus (179 steps) in analyses where the position of Gomortega was also unconstrained. All four most parsimonious trees place Saportanthus within core Laurales. C, Most parsimonious position (184 steps) of Saportanthus and Jamesrosea in the fixed backbone tree. D, Most parsimonious position (179 steps) of Saportanthus and Jamesrosea in analyses where the position of Gomortega was also unconstrained.

in the more restricted data set compiled for Laurales by Renner (1999).

Experiments with the full Doyle and Endress morphological data set supported a position for Saportanthus among extant lineages of Laurales with the most parsimonious position as sister to core Laurales (1024 steps) but with two alternative positions requiring only one more step: sister to the clade comprising Monimiaceae (including Monimioideae, Mollinedioideae, and Hortonia) plus Lauraceae-Hernandiaceae (including Hernandioideae and Gyrocarpoideae) or sister to the LauraceaeHernandiaceae clade.

Experiments with the Laurales subset gave similar results. The most parsimonious position for Saportanthus was sister to core Laurales (184 steps; fig. 14A), but positions as sister to the Monimiaceae-Lauraceae-Hernandiaceae clade, as sister to the Lauraceae-Hernandiaceae clade, or as sister to Gomortega alone were only one step less parsimonious.

Removing the monotypic genus Gomortega from the backbone tree and testing the position of both Gomortega and Saportanthus on all possible branches in the remaining Laurales backbone tree resulted in four equally parsimonious trees (179 steps): with Gomortega and Saportanthus resolved as sister taxa and placed as the sister group to the LauraceaeHernandiaceae clade (fig. 14B), with Gomortega and Saportanthus as successive sisters (in different orders) to the LauraceaeHernandiaceae clade, or with Saportanthus as sister to the Monimiaceae, Gomortega, and Lauraceae-Hernandiaceae.

Using the Laurales subset, we also tested the position of $\mathrm{Sa}$ portanthus in analyses that included two additional fossil lauralean taxa with multipartite flowers (Lovellea and Jamesrosea; 
see "Other Early and Mid-Cretaceous Laurales" below). In analyses including only Saportanthus and Jamesrosea, the most parsimonious position for Saportanthus (184 steps) is sister to all core Laurales, while Jamesrosea is placed as sister to Gomortega (fig. 14C). However, other positions for the two fossils among core Laurales are only one to a few steps longer. Removing Gomortega from the backbone tree and testing its position simultaneously with Saportanthus and Jamesrosea resulted in one most parsimonious tree with Jamesrosea, SaportanthusGomortega, and Lauraceae-Hernandiaceae as successive sisters (179 steps; fig. 14D). Several other topologies with Jamesrosea, Saportanthus, and Gomortega in various positions next to Lauraceae-Hernandiaceae are only one step less parsimonious. Experiments that added Lovellea to the data set reduced the strength of the link between Saportanthus and Gomortega.

Testing the position of Saportanthus in the data set for Laurales developed by Renner (1999), using the strict consensus tree of Renner as a backbone tree, resulted in a most parsimonious position for Saportanthus nested within core Laurales as sister to Hernandiaceae. In this data set, a position for $\mathrm{Sa}$ portanthus as sister to Gomortega is two steps less parsimonious.

Most of the phylogenetic analyses we deployed place Saportanthus in the Laurales, although the exact position is not clearly resolved. In analyses in which the backbone tree is unchanged, Saportanthus is resolved as sister to core Laurales, but other positions among core Laurales are only one or a few steps less parsimonious. In analyses where the backbone tree was relaxed by not constraining the position of one or more of the extant taxa, Saportanthus is resolved as nested within core Laurales, most often with Gomortega and Lauraceae-Hernandiaceae. Adding fossils to the analyses also changed the topology. As has often been pointed out, sampling may have a significant effect on phylogenetic results (e.g., Graybeal 1998; Renner 1999). Use of a fixed backbone tree of extant taxa therefore may provide only a rough guide to the systematic position of a fossil taxon, particularly for early angiosperms (including Laurales), for which extinction of relevant early lineages is well documented.

\section{Other Early and Mid-Cretaceous Laurales}

Saportanthus provides the first floral evidence of Laurales in Early Cretaceous floras from Portugal. Leaf fossils from the basal part of the Figueira da Foz Formation at Juncal, close to the Vale de Água locality, include several impressions of leaves with features that also indicate a relationship with Laurales (work in progress). However, pollen grains similar to those found in the flowers of Saportanthus have not been observed in the palynological assemblages associated with the mesofossil floras or from other dispersed palynological assemblages. The small size of the grains, the very thin pollen wall, and the fine exine ornamentation also suggest that the grains, if present, would be difficult to recognize in traditional light microscopy surveys of dispersed grains. As noted in previous studies (Drinnan et al. 1990; Herendeen et al. 1994), the palynological record almost certainly significantly underestimates the significance of Laurales in Cretaceous vegetation.

Fossil floral structures thought to be closely related to extant Laurales are relatively common in Cretaceous floras. From later stages of the Late Cretaceous, other lauralean floral structures include several taxa closely related to Lauraceae (Herendeen et al. 1994; Eklund 2000) as well as Jerseyanthus calycanthoides (Crepet et al. 2005), which is similar to extant Calycanthaceae. Especially significant is the distinctive genus Mauldinia, which was widespread in the early Late Cretaceous, with records in eastern North America (Drinnan et al. 1990), Europe (Eklund and Kvaček 1998; Viehofen et al. 2008; Moreau et al. 2016), and central Asia (Frumin et al. 2004), and has flowers very similar to those of extant Lauraceae, with trimerous perianth and stamen whorls, stamens with paired staminal appendages, and anthers that dehisce by apically hinged valves. Mauldinia was first described on the basis of flowers, inflorescence axes, and fruits from the early Cenomanian (Late Cretaceous) of eastern North America (Drinnan et al. 1990).

Also from the mid-Cretaceous and of probale lauralean relationships are Lovellea vintonensis from western Queensland, Australia, and three extinct taxa (Palaeoanthella, Cascolaurus, and Jamesrosea) preserved in amber from Myanmar (Burmese amber) that may be of early Cenomanian age (Shi et al. 2012).

Lovellea vintonensis is a permineralized fruiting structure with remains of floral organs (Dettmann et al. 2009). The receptacle is cup shaped with numerous tepals and stamens borne on the rim of the floral cup and numerous carpels embedded in the hypanthium wall. Phylogenetic analysis resolves Lovellea as sister to core Laurales and highlights several features that are similar to Gomortega. Lovellea has dicolpate pollen, as in Saportanthus, but is distinct in the much greater number of floral parts and carpels and the bisporangiate anthers that are introrse and dehisce by apically hinged valves.

Palaeoanthella huangii (Poinar and Chambers 2005) is a male flower with eight tepals and eight stamens apparently in a whorled arrangement. It was provisionally compared to flowers of extant Monimiaceae, but few details are reported and its systematic affinity is uncertain. Cascolaurus burmitis (Poinar 2017) is a trimerous staminate flower compared to flowers of extant Litsea (Lauraceae). Better understood-and also from the Burmese amber-is Jamesrosea burmensis, which is distinguished from Saportanthus by its apocarpous gynoecium and the presence of staminal appendages, bisporangiate anthers, and extrorse anther dehiscence by apically hinged valves. Jamesrosea and Saportanthus are, however, similar in their multipartite flowers and presence of several carpels. Both may be closely related to extant Gomortega. Phylogenetic analyses place Jamesrosea as sister to the Atherospermataceae-Gomortegaceae clade (Crepet et al. 2016).

Along with Saportanthus, Araripia florifera from the late Aptian-early Albian Crato Formation of Brazil and four lauralean flowers from the early-middle Albian Puddledock mesofossil flora of eastern North America currently provide the only floral evidence of Laurales in the Early Cretaceous.

Araripia florifera is a leafy branching axis bearing floral structures that have many apparently undifferentiated perianth parts in a spiral arrangement on a cup-shaped receptacle (Mohr and Eklund 2003). The strongly compressed nature of the fossils precludes detailed comparison with extant taxa, but Mohr and Eklund (2003) suggested a close relationship with Calycanthaceae. 
Stronger evidence of Calythcanthaceae is provided by the flower of Virginianthus calycanthoides from the Puddledock locality (Friis et al. 1994). Virginianthus is similar to flowers of Calycanthaceae in the spiral arrangement of the floral parts and the lack of staminal appendages as well as having anther dehiscence by longitudinal slits and a multicarpellate gynoecium (Friis et al. 1994a). Also in the Puddledock mesofossil flora, Potomacanthus lobatus (von Balthazar et al. 2007), Cohongarootonia hispida (von Balthazar et al. 2011), and Powhatania connata (von Balthazar et al. 2011) provide evidence of core Laurales close to the Monimiaceae-Lauraceae-Hernandiaceae clade. All have tepals and stamens in trimerous whorls and stamens with staminal appendages. In addition, anther dehiscence in these fossils (where known) is by apically hinged valves, and the gynoecium is unicarpellate (von Balthazar et al. 2011).

\section{Conclusion}

Fossil flowers of Saportanthus provide the first floral evidence of Laurales from the Early Cretaceous of Europe. Phylogenetic analyses place Saportanthus within Laurales, either as sister to, or embedded within, core Laurales. The single ovule per carpel seen in Saportanthus is a feature that characterizes all extant core Laurales and distinguishes them from its sister group (Calycanthaceae), in which there are two ovules per carpel. The valvate anther dehiscence with laterally hinged valves in Saportanthus is very similar to that of Sinocalycanthus but is distinct from the longitudinal dehiscence in other members of the family. Among other characters of Saportanthus, the irregular number and spiral arrangement of floral parts and the syncarpous, (semi)-inferior gynoecium, typically of two or three carpels, are features shared with Gomortega. Furthermore, dicolpate (but not trichotomocolpate) pollen with a continuous exine occurs among core Laurales in Atherospermataceae as well as in the fossil flower Lovellea.

Several features of Saportanthus may also be plesiomorphic for Laurales as a whole and thus may help bridge the deep mor- phological split between Calycanthaceae and all other Laurales noted by Renner (1999). Saportanthus and Calycanthaceae both lack paired staminal appendages that are otherwise characteristic for most core Laurales (except Siparunaceae and Mollinedioideae). Anthers are also tetrasporangiate in Saportanthus, while they are bisporangiate in Siparunaceae, Gomortegaceae, Atherospermataceae, Hernandiaceae, and many Lauraceae. Saportanthus and Calycanthaceae also share the unusual feature of dicolpate pollen, although in pollen of Calycanthaceae the colpi are nearly equatorial rather than placed more distally, as in Saportanthus.

Nevertheless, despite these similarities Saportanthus cannot be placed confidently in any existing family or subclade of Laurales, and the three species described here conclusively establish the presence of a lineage that is now extinct. Detailed investigation of Cretaceous flowers is still at a very early stage, and the fossils discovered to date undoubtedly represent only a tiny fraction of the extinct diversity. Evidence of extinction among early angiosperms related to Laurales is already considerable, including the fossil flowers of Saportanthus, Virginianthus, Lovellea, Jerseyanthus, and Jamesrosea. This implies that detailed interpretations of patterns of character evolution within the group based solely on extant taxa are almost certainly premature and are unlikely to provide a reliable model of actual patterns of character change in lauralean evolution.

\section{Acknowledgments}

We thank Marco Stampanoni, Federica Marone, and Anna Lindström for help with the SRXTM analyses performed at the Swiss Light Source, Paul Scherrer Institute, Villigen, Switzerland. This research was supported by the Swiss Light Source (European Union FP6 project 2016140 as well as several previous projects to P. C. J. Donoghue, S. Bengtson, and E. M. Friis) and by the Swedish Research Council (2014-5228 to E. M. Friis).

\section{Literature Cited}

APG (Angiosperm Phylogeny Group) 2016 An update of the Angiosperm Phylogeny Group classification for the orders and families of flowering plants: APG IV. Bot I Linn Soc 181:1-20.

Brizicky GK, G Buchheim 1959 Variability in the floral parts of Gomortega (Gomortegaceae). Willdenowia 2:200-207.

Buchheim G 1958 Bemerkungen zum Andrözeum der Gomortegaceae. Willdenowia 2:27-31.

Crepet WL, KC Nixon, MA Gandolfo 2005 An extinct calycanthoid taxon, Jerseyanthus calycanthoides, from the Late Cretaceous of New Jersey. Am I Bot 92:1475-1485.

Crepet WL, KC Nixon, D Grimaldi, M Riccio 2016 A mosaic lauralean flower from the Early Cretaceous of Myanmar. Am I Bot 103:290-297.

Dettmann ME, HT Clifford, M Peters 2009 Lovellea wintonensis gen. et sp. nov.-Early Cretaceous (late Albian), anatomically preserved, angiosperm flowers and fruits from the Winton Formation, western Queensland. Cretac Res 30:339-355.

Dinis JL 2001 Definição da Formação da Figueira da Foz-Aptiano a Cenomaniano do sector central da margem oeste ibérica [Definition of the Figueira da Foz Formation-Aptian to Cenomanian of the central sector of the western Iberian margin]. Com Inst Geol Mineiro 88:127-160.

Dinis JL, J Rey, PP Cunha, P Callapez, R Pena Dos Reis 2008 Stratigraphy and allogenic controls of the western Portugal Cretaceous: an updated synthesis. Cretac Res 29:772-780.

Dinis JL, J Rey, P-CD Graciansky 2002 Le bassin lusitanien (Portugal) à l'Aptien supérieur-Albien: organisation séquentielle, proposition de corrélations, évolution. CR Geosci 334:757-764.

Doweld AB 2001 Carpology and phermatology of Gomortega (Gomortegaceae): systematic and evolutionary implications. Acta Bot Malacit 26:19-37.

Doyle JA, PK Endress 2000 Morphological phylogenetic analysis of basal angiosperms: comparison and combination with molecular data. Int I Plant Sci 161(suppl):S121-S153.

2010 Integrating Early Cretaceous fossils into the phylogeny of living angiosperms: Magnoliidae and eudicots. I Syst Evol 48:135.

2014 Integrating Early Cretaceous fossils into the phylogeny of living angiosperms: ANITA lines and relatives of Chloranthaceae. Int I Plant Sci 175:555-600. 
Drinnan AN, PR Crane, EM Friis, KR Pedersen 1990 Lauraceous flowers from the Potomac Group (mid-Cretaceous) of eastern North America. Bot Gaz 151:370-384.

Eklund H 2000 Lauraceous flowers from the Late Cretaceous of North Carolina, USA. Bot I Linn Soc 132:397-428.

Eklund H, J Kvaček 1998 Lauraceous inflorescences and flowers from the Cenomanian of Bohemia (Czech Republic, central Europe). Int I Plant Sci 159:668-686.

Endress PK, JA Doyle 2009 Reconstructing the ancestral angiosperm flower and its initial specializations. Am I Bot 96:22-66.

2015 Ancestral traits and specializations in the flowers of the basal grade of living angiosperms. Taxon 64:1093-1116.

Endress PK, LD Hufford 1989 The diversity of stamen structures and dehiscence patterns among Magnoliidae. Bot I Linn Soc 100:45-85.

Friis EM, PR Crane, KR Pedersen 2011 Early flowers and angiosperm evolution. Cambridge University Press, Cambridge.

Friis EM, H Eklund, KR Pedersen, PR Crane 1994a Virginianthus calycanthoides gen. et sp. nov. - a calycanthaceous flower from the Potomac Group (Early Cretaceous) of eastern North America. Int I Plant Sci 155:772-785.

Friis EM, GW Grimm, MM Mendes, KR Pedersen 2015 Canrightiopsis, a new Early Cretaceous fossil with Clavatipollenites-type pollen bridge the gap between extinct Canrightia and extant Chloranthaceae. Grana 54:184-212.

Friis EM, F Marone, KR Pedersen, PR Crane, M Stampanoni 2014 Three-dimensional visualization of fossil flowers, fruits, seeds and other plant remains using synchrotron radiation X-ray tomographic microscopy (SRXTM): new insights into Cretaceous plant diversity. I Paleontol 88:684-701.

Friis EM, MM Mendes, KR Pedersen 2017 Paisia, an Early Cretaceous eudicot angiosperm flower with pantoporate pollen from Portugal. Grana. doi:10.1080/00173134.2017.1310292.

Friis EM, KR Pedersen, PR Crane 1994b Angiosperm floral structures from the Early Cretaceous of Portugal. Plant Syst Evol Suppl 8:31-49.

2000 Reproductive structure and organization of basal angiosperms from the Early Cretaceous (Barremian or Aptian) of western Portugal. Int I Plant Sci 161(suppl):S169-S182.

2010 Cretaceous diversification of angiosperms in the western part of the Iberian Peninsula. Rev Palaeobot Palynol 162:341-361.

Frumin S, H Eklund, EM Friis 2004 Mauldinia hirsuta sp. nov., a new member of the extinct genus Mauldinia (Lauraceae) from the Late Cretaceous (Cenomanian-Turonian) of Kazakhstan. Int I Plant Sci 165:883-895.

Furness CA, PJ Rudall 1999 Microsporogenesis in monocotyledons. Ann Bot 84:475-499.

2003 Apertures with lids: distribution and significance of operculate pollen in monocotyledons. Int I Plant Sci 164:835-854.

Furness CA, PJ Rudall, FB Sampson 2002 Evolution of microsporogenesis in angiosperms. Int I Plant Sci 163:235-260.

Furness CA, G Thomas, PJ Rudall 2015 Pollen structure and diversity in Liliales. Int I Plant Sci 176:697-723.

Graybeal A 1998 Is it better to add taxa or characters to a difficult phylogenetic problem? Syst Biol 47:9-17.

Harley MM 1996 Palm pollen and the fossil record. PhD Thesis. University of East London.

Herendeen PS, WL Crepet, KC Nixon 1994 Fossil flowers and pollen of Lauraceae from the Upper Cretaceous of New Jersey. Plant Syst Evol 189:29-40.

Hesse M, K Kubitzki 1983 The sporoderm ultrastructure in Persea, Nectandra, Hernandia, Gomortega and some other Lauralean genera. Plant Syst Evol 141:299-311.

Kubitzki K 1993 Gomortegaceae. Pages 318-320 in K Kubitzki, JG Rohwer, V Bittrich, eds. The families and genera of vascular plants. II. Flowering plants - dicotyledons. Magnoliid, hamamelid and caryophyllid families. Springer, Berlin.

Leinfellner W 1968 Über die Karpelle verschiedener Magnoliales. VI. Gomortega keule (Gomortegaceae). Osterr Bot Z 115:113-119.
Maddison WP, DR Maddison 2017 Mesquite: a modular system for evolutionary analysis. Ver 3.2. http://mesquiteproject.org.

Mendes MM, J Dinis, J Pais, EM Friis 2014 Vegetational composition of the Early Cretaceous Chicalhão flora (Lusitanian Basin, western Portugal) based on palynological and mesofossil assemblages. $\underline{\text { Rev }}$ Palaeobot Palynol 200:65-81.

Mohr BAR, H Eklund 2003 Araripia florifera, a magnoliid angiosperm from the Lower Cretaceous Crato Formation (Brazil). $\underline{\text { Rev }}$ Palaeobot Palynol 126:279-292.

Moreau J-D, B Gomez, V Daviero-Gomez, D Néraudeau, P Tafforeau 2016 Inflorescences of Mauldinia sp. (Lauraceae) and associated fruits from the Cenomanian of Languedoc Roussillon, France. Cretac Res 59:18-29.

Nadot S, A Forchioni, L Penet, J Sannier, A Ressayre 2006 Links between early pollen development and aperture pattern in monocots. Protoplasma 228:55.

Poinar G 2017 A mid-Cretaceous Lauraceae flower, Cascolaurus burmitis gen. et sp. nov., in Myanmar amber. Cretac Res 71:96-101.

Poinar G, KL Chambers 2005 Palaeoanthella huangii gen. et sp. nov., an Early Cretaceous flower (Angiospermae) in Burmese amber. Sida 21:2087-2092.

Remizowa MV, DD Sokoloff, TD Macfarlane, SR Yadav, CJ Prychid, PJ Rudall 2008 Comparative pollen morphology in the earlydivergent angiosperm family Hydatellaceae reveals variation at the infraspecific level. Grana 47:81-100.

Renner SS 1999 Circumscription and phylogeny of Laurales: evidence from molecular and morphological data. Am I Bot 86:13011315.

Renner SS, AS Chanderbali 2000 What is the relationship among Hernandiaceae, Lauraceae, and Monimiaceae, and why is this question so difficult to answer? Int I Plant Sci 161(suppl):S109-S119.

Rey J 1993 Les unités lithostratigraphiques du groupe de Torres Vedras (Estremadura, Portugal). Comun Inst Geol Min 79:75-85.

Rey J, JL Dinis, P Callapez, PP Cunha 2006 Da rotura continental à margem passiva: composição e evolução do Cretácico de Portugal. Ministério da Economia e da Inovação, Lisbon.

Rudall PJ 2002 Unique floral structures and iterative evolutionary themes in Asparagales: insights from a morphological cladistic analysis. Bot Rev 68:488-509.

Sampson FB 1987 Disulculate pollen in the Trimeniaceae. Grana 26: 239-241.

Sampson FB, PK Endress 1984 Pollen morphology in the Trimeniaceae. Grana 23:129-137.

Schols P, CA Furness, P Wilkin, S Huysmans 2001 Morphology of pollen and orbicules in some Dioscorea species and its systematic implications. Bot _ Linn Soc 136:295-311.

Schols P, CA Furness, P Wilkin, E Smets, V Cielen, S Huysmans 2003 Pollen morphology of Dioscorea (Dioscoreaceae) and its relation to systematics. Bot I Linn Soc 143:375-390.

Shi G, DA Grimaldi, GE Harlow, J Wang, J Wang, M Yang, W Lei, Q Li, X Li 2012 Age constraint on Burmese amber based on U-Pb dating of zircons. Cretac Res 37:155-163.

Staedler YM, PK Endress 2009 Diversity and lability of floral phyllotaxis in the pluricarpellate families of core Laurales (Gomortegaceae, Atherospermataceae, Siparunaceae, Monimiaceae). Int I Plant Sci 170:522-550.

Staedler YM, PH Weston, PK Endress 2007 Floral phyllotaxis and floral architecture in Calycanthaceae (Laurales). Int _ Plant Sci 168:285-306.

Stampanoni M, A Groso, A Isenegger, G Mikuljan, Q Chen, A Bertrand, S Henein, et al 2006 Trends in synchrotron-based tomographic imaging: the SLS experience, p. 780410-1/11. Page 6318 in U Bonse. Developments in X-ray tomography V. Proceedings of the Society of Photo-Optical Instrumentation Engineers (SPIE).

Taylor ML, BL Gutman, NA Melrose, AM Ingraham, JA Schwartz, JM Osborn 2008 Pollen and anther ontogeny in Cabomba caroliniana (Cabombaceae, Nymphaeales). Am I Bot 95:399-413. 
Waha M, W Morawetz 1988 Pollen evolution and systematics in Annonaceae with special reference to the disulcate Australian endemic genera. Plant Syst Evol 161:1-12.

Walker JW 1974 Aperture evolution in the pollen of primitive angiosperms. Am I Bot 61:1112-1137.

Viehofen A, C Hartkopf-Fröder, EM Friis 2008 Inflorescences and flowers of Mauldinia angustiloba sp. nov. (Lauraceae) from midCretaceous karst infillings in the Rhenish Massif, Germany. Int I Plant Sci 169:871-889.

Wilkin P, C Liz, F Clive, P Schols 2000 A new species of Dioscorea (Dioscoreaceae) from Eastern Madagascar and its pollen morphology. Kew Bulletin 55:427-434.

Wilkin P, AM Muasya, H Banks, CA Furness, K Vollesen, O Weber, S Demissew 2009 A new species of yam from Kenya, Dioscorea kituiensis: pollen morphology, conservation status, and speciation. Syst Bot 34:652-659.

Wilson TK 1964 Comparative morphology of the Canellaceae. III. Pollen. Bot Gaz 125:192-197.

von Balthazar M, PR Crane, KR Pedersen, EM Friis 2011 New flowers of Laurales from the Early Cretaceous (early to middle Albian) of eastern North America. Pages 49-87 in L Wanntorp, LP Ronse De Craene, eds. Flowers on the tree of life. Cambridge University Press, Cambridge. von Balthazar M, KR Pedersen, PR Crane, M Stampanoni, EM Friis 2007 Potomacanthus lobatus gen. et sp. nov., a new flower of probable Lauraceae from the Early Cretaceous (early to middle Albian) of eastern North America. Am I Bot 94:2041-2053.

Zavada MS 1983 Comparative morphology of monocot pollen and evolutionary trends of apertures and wall structures. Bot Rev 49:331-379. 